\title{
APUNTES SOBRE EL MINISTERIO EN SAN IRENEO (LA SENCILLEZ DE DIOS Y DEL HOMBRE)
}

\section{Mons. Eugenio Romero Pose in memoriam •}

DOI: https://doi.org/10.52039/seminarios.v53i186.560

Autor: Mons. Eugenio Romero Pose. Obispo auxiliar de Madrid.

\section{Introducción}

Muchos son los trabajos sobre el ministerio en los Santos Padres. Para una amplia y rica bibliografía basta hojear los volúmenes publicados por la Facultad de Teología de Burgos sobre la Teología del sacerdocio ${ }^{1}$. Abundan las aproximaciones a la teología del ministerio ordenado en la literatura de los llamados Padres Apostólicos, no pocas veces envueltas en apasionadas polémicas como la controvertida y no resuelta cuestión ignaciana $^{2}$. No escasea la búsqueda de las aportaciones de la tradición alejan-

- El día 25 de marzo fallecía en Madrid Monseñor Eugenio Romero Pose. Queremos dedicarle el presente número de la Revista con la publicación de este artículo que pugnaba por ver la luz desde hace tiempo. La altura del mismo nos muestra un poco el alma investigadora y sacerdotal de D. Eugenio. Al sencillo y ejemplar sacerdote, obispo y amigo.

1 J. Esquerda Bifet, Orientación bibliográfica. Estudios históricos sobre espiritualidad sacerdotal, en: Teología del sacerdocio 19, Burgos 1985, pp. 221-236. 
drina y africana, con especial atención a Orígenes, Tertuliano y Cipriano. Interesan las sistematizaciones de los autores tardíos, ya griegos ya latinos, especialmente los del denominado siglo de oro, el s V. En cambio, menos atención ha merecido la tradición asiática, la más rica de las tradiciones patrísticas por su cercanía a las tradiciones apostólicas. Es de sobra conocido que su proximidad a la mentalidad semítica favoreció el acopio de lecturas y arcaicas interpretaciones bíblicas que fueron obviadas por otras tradiciones. Y afirmar que la tradición asiática es heredera de singulares exégesis es tanto como decir que su teología es asimismo muy propia con relación a otras iglesias.

El autor que con más hondura ha sabido sintetizar las riquezas de esta tradición es Ireneo de Lyón, a pesar del posterior olvido en la historia del pensamiento cristiano. Todavía estamos muy lejos de haber redescubierto, y mucho menos agotado, la escandalosa originalidad de la teología asiática que conservó rasgos diluidos por otros autores, en especial los alejandrinos, impelidos a exponer la verdad cristiana en ámbitos geográfico-culturales que le imponían esquemas muy lejanos al entorno bíblico y forzaban el ocultamiento de determinadas perspectivas. En la obra literaria ireneana que milagrosamente ha llegado hasta nosotros - gracias a la versión latina del Adversus haereses (probablemente hispánica) y a la armenia de la Epideixis - quedó reflejada no solo una de las primeras teologías sobre el ministerio sino que se nos ofrece la experiencia concreta que el obispo de Lyón tenia del ministerio ordenado ${ }^{3}$. No es de minusvalorar lo que San Ireneo, en los rasgos autobiográficos, dejó plasmado en sus escritos. En nuestros días se empieza a conceder importancia a la antropología del texto, es decir, a la experiencia que el autor deja impresa en su obra ${ }^{4}$. Es posible entrever en la persona del obispo de Lyón la plasmación de su concepción del ministerio.

Investigaciones sobre el ministerio y sacerdocio en S. Ireneo han señalado su grandeza tanto en la iglesia oriental como en la occidental y han

2 Cf. J. Rius Camps, Die echten Briefe des Ignatius von Antiochien, Revista Catalana de Teología XVI/1 (1991) 67-103; Sucesión y ministerios en las Pseudoclementinas, en: Teología del sacerdocio 9, Burgos 1977, pp. 165-215.

3 Cf. O. Celada, Ministerio y tradición en San Ireneo, en. Teología del sacerdocio 9. La potestad de orden en los primeros siglos, Burgos 1977, p. 161: En su vida y obra realiza la función ministerial con una fuerza y una constancia propias de quien se siente llamado, podíamos decir que implícitamente investido, para ejercer el poder propio de su orden y sucesión, es decir, el de los epíscopos y presbíteros". 
subrayado la hondísima conexión entre ministerio y Traditio. No podía ser de otro modo dado que a Ireneo le tocó -condicionado por la controversia gnóstica- fijar el concepto teológico de Tradición eclesial. Era, pues, de sospechar que el gran defensor de la Traditio guardara hondos perfiles sobre el ministerio. En este sentido discurren los estudios de, entre otros, E. Lanne 5 , J.A. de Aldama ${ }^{6}$ y G. Celada ${ }^{7}$.

Así pues, los estudiosos de la tradición asiática, -que conecta directamente con la predicación joannea- se han atenido a aspectos del ministerio que miran más bien a su estructura sacramental, y su relación con la Tradición, que a la conexión del ministerio con el Dios cristiano, es decir, la relación ministerio-Trinidad. Si bien es cierto que esta última dimensión está necesariamente presente siempre que se contemple la realidad del misterio cristiano. También es obvio que el ministerio es referencia teológica obligada que aflora cuando nos aproximamos a la revelación del Dios trino ${ }^{8}$.

Por mi parte quiero apuntar alguna característica del ministerio9, especialmente querida por Ireneo, y aspectos relacionados con la revelación neo-testamentaria, es decir, con la novedad que el Verbo encarnado aporta al ministerio cristiano. Y todo ello desde la vivencia del ministerio en el obispo de Lyón, en una época en que la teología del ministerio se encuentra todavía en pleno desarrollo. No es justo querer hallar en Ireneo aspectos posteriores y forzar sus textos tanto en lo que silencia corno en lo que afirma.

Entre las características destaco, al filo del texto ireneano, la simplicidad. Me atendré a lo que los textos no enseñan siempre que se utiliza el

\footnotetext{
${ }^{4} \mathrm{La}$ antropología del texto comenzó a ser aplicada, desde los estudios de antropología cultural, a los textos clásicos y ahora a los textos bíblicos, cf. A. Destro-M. Pesce, Antropologia delle origini cristiane, Laterza, Bari 1995.

${ }^{5}$ Le ministere apostolique dans l'ouvre de Saint Irénée, Irenikon 25 (1952)113-141.

${ }^{6} \mathrm{El}$ sacerdocio ministerial en San Ireneo, en: Teología del sacerdocio 4. Teología del sacerdocio en los primeros siglos, Burgos 1972, pp. 113-142.

${ }^{7}$ Ministerio y tradición en San Ireneo..., o.c. (n. 3), pp. 121-162.

8 Esta relación ministerio-Trinidad aparece implícito en los estudios ireneanos; cf, a modo de ejemplo, Últimamente J. Fantino, La théologie d'Irénée. Lecture des Ecritures en réponse á l'exégèse gnostique.Une approche trinitaire, Du Cerf, Paris 1994, esp. pp. 28-54.

9 En otra ocasión me fijé en la relación ministerio-Tradición, cf Los "muchos" y los "pocos". Pueblo de Dios, ministerio y Tradición, en: Teología del sacerdocio. Ministerio. Tradición y Regia de fe en los tres primeros siglos, Burgos 1990, pp. 151-182.
} 
término simplicidad o sencillez (que el traductor latino tradujo las más de la veces por simpliciter). Que yo sepa nadie ha resaltado, quizás por ser demasiado obvio, este aspecto en relación al ministerio. Sin embargo la abundante frecuencia del mismo en Ireneo invitaba al análisis. Renuncio, en esta ocasión, a comparar el uso de $\alpha \pi \lambda o \varsigma$ (sencillo) en los círculos filosóficos - especialmente en la tradición platónica, aplicado a la divinidad-y el influjo que pudo ejercer este clima cultural en el pensamiento teológico ireneano ${ }^{10}$. No es mi intención desarrollar todos los aspectos que ofrecen los textos. Mi propósito es presentar, a modo de centón (kéntrón), una selección de textos ireneanos que puedan dar pie a desarrollos posteriores.

Es imposible ejercer el ministerio en sencillez si no está todo él referido al misterio trinitario. No hay ministerio eclesial que no nazca de la diakonía del Hijo y del Espíritu y del beneplácito del Padre. El amor de Dios Padre es el origen del servicio; y la manifestación de este amor se revela en la diakonía filial manifestada como acción del Espíritu.

Pero el permanente peligro del orgullo que puede adueñarse de los, en expresión ireneana, "adornados por el sobreeminente ministerio" hace que aparezca el aspecto contrapuesto a todo servicio. Desde esta óptica la fuerza del ministerio se cimienta en el beneplácito del Padre y gracias al Espíritu, que otorga la gnosis verdadera, goza del carisma seguro de la verdad.

\section{La sencillez en el ministerio eclesial}

Ireneo, en el prólogo al libro $\mathrm{V}$ del $A d v$. Haer. responde, como obispo, a alguien que le demanda información sobre las desviaciones cristianas -la doctrina de los herejes- y soluciones a las mismas:

"Así nos lo demandaste, y obedecemos a tu precepto, tanto más que fuimos ordenados para la administración de la palabra (cf Act 6,4; Lc $1,2)$, y no ahorramos trabajo, según nuestras posibilidades, a fin de poner muchísimos elementos a tu disposición, para que contradigas a los herejes, reconquistes a los errabundos y los conviertas a la Iglesia de Dios; confirmes asimismo el interior de los neófitos, para que mantengan firme la fe que, fielmente custodiada, recibieron de la Iglesia, y en modo algu-

10 Ireneo también se resiente, no podía ser de otro modo, del influjo e inspiración platónicos, cf A. Orbe, A propósito de dos citas de Platón en San Ireneo, Haer. V,24,4, en: Orpheus N.S. 1V12 (1983) 253-285. 
no se dejen desviar por quienes se esfuerzan en adoctrinarles mal y apartarlos de la verdad"11.

Mucho le promete y para mucho se siente capacitado el santo, pues mucho le exige a quien se dirige: que contradiga a los errados, que reconquiste a los extraviados, que confirme a los que comienzan y que mantenga firme la fe de los que se consideran avanzados en el camino cristiano.

Más aún, el obispo de Lyón es consciente dc que no expone el mensaje cristiano sólo por corresponder a la amistosa petición de un amigo ${ }^{12}$ sino "por estar también él colocado al servicio de la Palabra". Este ministerio le vincula primariamente al servicio de la Palabra por sentirse asociado a la misma misión de los apóstoles. Ministerio, apostolado y Palabra aparecen vertebrados, como un unum, en la existencia de Ireneo.

La administración de la Palabra, como cometido del ministerio, parece remitir, en el texto ireneano, a Hech 6,413 , en donde se señala que lo propio de los apóstoles, cuando la elección de los diáconos, es "la oración y el ministerio de la Palabra". La oración incluiría la dimensión litúrgica aunque aquí a Ireneo le urge resaltar más el servicio a la Palabra. Ireneo tiene en cuenta Lc 1,2 en el que el evangelista advierte el intento de recoger por escrito lo que habían transmitido los apóstoles, es decir, los "testigos oculares y después ministros de la Palabra"14.

El obispo de Lyón además de referirse a Hech 6,4 y Lc 1,2 puede que tenga presente, al escribir que fue ordenado para la administración de la palabra, 1 Tim 1,12 (“doy gracias al que me dio fuerzas, a Cristo Jesús,

${ }^{11} \mathrm{AH} \mathrm{V}$, pr. (SC 153, p. 12): “... Quemadmodum postulasti a nobis, oboedientibus tuo praecepto, quoniam et in administrationem sermonis positi sumus (cf. Act 6,$4 ; \mathrm{Lc} 1,2$ ), et omni modo elaborantibus secundum nostram virtutem plurima tibi quidem in subsidium praestare: adversus contradictiones haereticorum, errantes autem retrahere et convertere ad ecclesiam Dei, neophytorum quoque sensum confirmare, ut stabilem custodiant fidem quam bene custoditam $\mathrm{ab}$ ecclesia acceperunt, et nullo modo transvertantur ab his qui male docere eos et abducere a veritate conantur". Cf A. Orbe, Teología de San Ireneo 1. Comentario al Libro V del "Adversus haereses", Madrid-Toledo 1985, 1, pp. 41-44.

12 Cf Ireneo, La demostración apostólica, FFt 2, Madrid 1992, p. 51.

13 Los pasajes de Hech y Lc tienen poca presencia en los escritos pre-nicenos. La Biblia Patrística, en los vols. 1-3 no señala referencia alguna para Hech 6,4, a excepción de dos citas en Orígenes. Lc 1,2 es citado tres veces (Tertuliano e Ireneo), otras tres en Pedro de Alejandría y en una carta a Pablo de Samosata y 12 veces en Origenes.

14 Seria interesante rescatar la influencia de estos dos versículos en la literatura patrística. Nada refiere -a propósito de Hech 6,4; Lc 1,2; 1 Tim 1,12; 2 Tim 1,11- H.J. Sieben, Exegesis Patrum. Saggio bibliografico sull'esegesi bíblica dei Padri della Chiesa, Roma 1983. 
Señor nuestro, porque me consideró digno de su confianza, poniéndome en el ministerio -ponens in ministerio-"), o 1 Tim 2,7 ("para cuya promulgación fui yo constituido heraldo y apóstol - in quod posítus sum ego praedicator et apostolus- (digo la verdad, no miento), maestro de los gentiles en la fe y en la verdad"), o 2 Tim 1,11 ("Para cuya predicación fui yo constituido heraldo y apóstol y maestro de los gentiles -in quo positus sum ego praedicator et apostolus et doctor-").

Ireneo, teniendo ante sus ojos estos pasajes bíblicos o tradiciones similares, se siente empujado por el ministerio de la Palabra, ministerio en el que ha sido constituido. De aquí se puede deducir que ejerció el ministerio episcopal, como apuntan Feuardent y Orbe, y que no fue solo presbítero como quiere Grabe ${ }^{15}$. Ireneo tiene conciencia de estar llamado a seguir los pasos del evangelista Lucas y del apóstol Pablo.

Ireneo, apegado al seguimiento de los apóstoles, escribe:

"Así los apóstoles, con simplicidad y sin negárselo a nadie, transmitían a todos lo que ellos mismos habían recibido del Señor. Del mismo modo también Lucas, sin negárselo a nadie, nos ha transmitido cuanto había recibido de ellos, como él mismo testimonia diciendo: "Como nos lo han transmitido los que desde el principio fueron testigos oculares y ministros del Verbo (Lc 1,2)"16.

Característica del ministerio, de los apóstoles y de sus seguidores, es la simplicidad con sencillez, sin complejidad- y la transmisión dirigida a todos de cuanto se ha recibido. Se da a entender que éstas son las pautas señaladas por los primeros testigos de los que el obispo de Lyón se siente seguidor. En el prefacio del AH I escribía que no promete el arte de la palabra, ni la habilidad en su exposición, ni un estilo retórico sino que quiere ofrecer el mensaje con amor, con sencillez, en verdad y sin artificio ${ }^{17}$. Al

15 Cf A. Orbe, Teología de San Ireneo..., o.c., II, p. 42. Es sabido que Ireneo intercambia indistintamente los nombres de obispo y presbítero.

16 AH III,14,2 (SC $211^{* *}$, p. 266): “... Sic apostolí simpliciter (haplós) et nemini inuidentes quae didicerant ipsi a Domino haec omnibus tradebant. Sic igitur et Lucas nemini inuidens ea quae ab eis didicerat tradidit nobis, sicut ipse testificatur dicens: Quemadmodum tradiderunt nobis qui ab initio contemplatores et ministrí fuerunt Verbi”.

17 AH I, praef 3 (SC 264, p. 24): "Nos autem exquires a nobis, qui apud Celtas commoramur et in barbarum sermonem plerumque vacamus, orationis artem, quam non didicimus, neque uim conscriptoris, quam non adfectauimus, neque ornamentum uerborum, neque suadelam, quam nescimus, sed simpliciter (haplós) et uere et idiotice ea quae tibi cum dilectione scripta sunt cum dilectione percipies...”. 
contrario de los gnósticos -los sectarios, los constructores de conventículos y no de Iglesia18 - que presentan la doctrina de la redención de un modo inestable e imposibilitan el anunciarla sencillamente y con un solo discurso, dado que cada uno de ellos lo transmite como quiere. Ireneo pone por delante que la simplicidad es el primer distintivo del apóstol, de aquél que ha recibido para entregar. Ser ministro de la palabra es ser servidor de la redención ${ }^{19}$, de lo que se le ha donado.

Lucas, compañero y discípulo de los apóstoles, propone a Zacarías, como ejemplo del que ejerce el ministerio sacerdotal (cf Lc 1,8-9), como el que sencillamente confiesa al Señor y Dios ${ }^{20}$, sencillez con la que el evangelista aprende y se propone transmitir los hechos y dichos del Verbo. Ireneo cuando en el pref. del libro $\mathrm{V}$ se refiere a la administración de la Palabra mira al ejemplo lucano ante sus ojos y gusta asimismo de presentar la figura de Zacarías como modelo del ejercicio sacerdotal resaltando también la sencillez o simplicidad. Entre Lucas e Ireneo hay perfecta continuidad a la hora de resaltar la actitud de la simplicidad.

S. Pablo, paradigma de apóstol, enseñaba sencillamente - no como los gnósticos- lo que conocía no sólo a sus compañeros sino a todos los que le escuchaban ${ }^{21}$. El proceder con sencillez era, para quien abrazase el estilo de los apóstoles, la mejor de las garantías de la universalidad, la única manera de que el mensaje alcanzase a todos. Únicamente con la sencillez se alcanza a todos.

18 Cf E. Romero Pose, La Gran Iglesia en la teoloría Primitiva en: Sentir con la Iglesia. Toledo 1983, pp. 39-49; G. M. Vian, Cristianismo y culturas en la época patrística, en: Cristianismo y Culturas, Valencia 1996, pp. 53-76.

${ }^{19} \mathrm{AH} \mathrm{1,21,1}$ (SC 264**, p. 294): "Redemptionis autem ipsorum traditionem euenit inuisibilem esse et incomprehensibilem, uidelicet cum sit incomprehensibilium et inuisibiliun mater. Et propter hoc, cum sit instabilis, non simpliciter (haplós) neque uno sermone referendum est, quoniam unusquisque illorum, quemadmodum ipsi uolunt, tradunt eam".

20 AH III,10,1 (SC 211**, p. 112): "Lucas autem, sectator et discipulus apostolorum, de Zacharia et Elizabeth ex quibus secundum repromissionem Dei Iohannes natus est referens ait: Erant autem iusti ambo ante Deum. incedentes in omnibus mandatis et institus Domini sine querela (Lc 1,6). Et iterum de Zacharia dicens: Factum est autem. cum sacerdotio fungeretur in ordine ulcis suae ante Deum. secundum consuetudinem sacerdotii sorte exiuit ut incensum poneret (Le 1,8-9), et uenit ut sacrificaret, intrans in templum Domini (Le 1,9): qui praeest in conspectu Dei, simpliciter (haplós) et absolute et firme Dominum et Deum confitens ex sua persona eum qui elegerit Ierusalem et legislationem sacerdotti fecerit, enius et est angelus Gabriel (cf. Lc. 1,11.19)".

${ }^{21}$ AH III,14,2 (SC 211**, p. 264): "Quoniam autem Paulus simpliciter (haplós) quae sciebat, haec et docuit, non solum eos qui cum eo erant, uerum omnes audientes se, ipse facit manifestum”. 
Nada extraña que Ireneo, en un contexto antignóstico, se sienta impelido a proponer la vida del Señor -lo que el Padre enseñó- de una manera llana y sencilla ${ }^{22}$, obvia y literal, y a proponer la sencillez como el camino más apto para el ejercicio del ministerio apostólico. El estilo sencillo invitaba al apego al sentido literal de la realidad y de la Escritura sin cejar ante la valoración de la historia con todas sus limitaciones.

No faltan al obispo de Lyón referencias bíblicas que avalan esta manera de pensar. He aquí alguna tradición exegética que reclamaban el estilo de ejercicio del ministerio en simplicidad. La palabra expuesta y el ministerio ejercido sencillamente es comparable -según antigua exégesis llegada a Ireneo- al vino nuevo de las bodas de Caná, vino hecho por el Señor rápida y sencillamente. No es que el vino producido de la vid no fuese bueno y no aprovechase a los que lo bebieron pero el vino nuevo, el gustado por los invitados a las bodas, es mejor ${ }^{23}$ por ser una realidad sencilla en el marco de la grandiosidad. No es difícil desvelar aquí una alusión a la eucaristía ${ }^{24}$ y al ministerio. Ireneo insinúa que a la característica de la sencillez en la exposición de la palabra corresponde la sencillez del vino nuevo. La sencillez de la palabra es fruto del poder de Dios al igual que el signo de las bodas de Caná y la eucaristía. El ministerio es, pues, un don del Espíritu como lo son las acciones -la eucaristía- que dependen de El. Probablemente Ireneo sugiera que a la sencillez de la palabra corresponde la sencillez de la ofrenda, y de modo singular a la sencillez de la eucaristía.

A Ireneo le place traer a la memoria los anuncios proféticos para mostrar cómo a lo largo de la historia Dios fue revelando lo que más podía convenir a la humanidad con miras al cumplimiento en Jesús. De este modo tomando pié en una exégesis veterotestamentaria Ireneo añade, en otro lugar, que la sencillez o simplicidad con que se debe administrar o servir la Palabra por parte de los constituidos en el ministerio recuerda la simplicidad de Eva, simplicidad opuesta a la malicia de la serpiente, a la astucia de la mentira. La simplicidad es el mejor soporte de la verdad.

${ }^{22}$ AH IV,41,4 (SC 100**, p. 994): "Reliquos igitur sermones Domini, quos quidem non per parabolas sed simpliciter ipsis dictionibus docuit de Patre...".

${ }^{23} \mathrm{AH}$ III,11,5 (SC 211**, pp. 152-154): "Bonurn enim et illud quod per conditionem a Deo in uinea facturn est et primo bibitum est uinum. Nemo enun illud uituperauit ex hlis qui biberunt, sed et Dominus accepit de eo; melius autem quod per Verbum compendialiter ac simpliciter (haplós) ex aqua ad usum eorum qui ad nuptias conuocati errant factum est uinum".

${ }^{24}$ Cf AH III,2,3; cf A. Orbe, Teología de San Ireneo..., o.c., pp. 143ss. 
Bien es cierto que hay simplicidad y simplicidad; la de Eva refiere con sencillez el precepto de Dios aunque con inexperiencia. La simplicidad de los justos se opone a las incertezas, o mejor aún, a la astucia, a la mentira. La mejor garantía para comunicar la fe es la simplicidad.

Eva, y los simpliciores significa la contraposición a la serpiente y a los astutos gnósticos ${ }^{25}$. Indica aquí el obispo de Lyón una interesante referencia a la sencillez como característica creatural que no debe ser olvidada en el nuevo régimen neotestamentario. La inexperiencia puede que incline a utilizar no correctamente la Palabra, pero no se puede ocultar la riqueza de la sencillez a pesar de que en el caso de Eva fuese preliminar de su caída. Nada se le acusará a quien actúa por simpleza y sin malicia ${ }^{26}$, todo se le imputará a quien se deje conducir por la mentira. La primera Eva contrasta con la nueva Eva, Maria. En una y otra refulge -por ser ambas plasis, creación, de Dios- la sencillez, aunque en la primera la inexperiencia le impedía la intelección literal, obvia, de la Palabra del Creador. La relación sencillez-verdad se sitúa en el corazón mismo del ministerio. Palabra y Verdad se identifican en el ejercicio del ministerio. No hay mayor contrasentido que el estar al servicio de la Palabra sino es desde la verdad.

La simplicidad vence a la astucia. Así la simplicidad de la paloma (cf Mt 10,16: "mirad, yo os envío como ovejas entre lobos: sed cautos como serpientes, cándidos como palomas") venció la astucia de la serpiente, rompió los lazos de la muerte ${ }^{27}$. Como es sabido la paloma puede significar simbólicamente o bien la Iglesia o bien el Espíritu. En este sentido podríamos referirnos a la simplicidad de la Iglesia. O al Espíritu que baja sobre Jesús en el Jordán. Desde esta segunda interpretación se deduce que la simplicidad del Espíritu de Dios que desciende sobre Jesús le llena plenamente, le invade, y hace a Jesús paloma. Es el Espíritu el que dinámicamente acompaña a la carne hacia la plenitud, hacia la resurrección. Es el Espíritu en abrazo con la sarx- el que vence con la simplicidad columbina a la astucia serpentina, a la muerte. Al intercambio entre el Espíritu

25 AH V,23,1 (SC 153**, p. 288): “... Et cum illa traduxisset mendacium et simpliciter retulisset praeceptum in eo quod diceret...”; cf A. Orbe, Teología de San Ireneo..., O.c. II, pp. 468470.

${ }^{26}$ AH V,30,1 (SC 153**, pp. 370-372): “... alii quidem simpliciter (haplós) et idiotice usurpauerunt denarium numerum, quidam autem et per ignorantiam ausi sunt... Sed his quidem qui simpliciter (haplós) et sine malitia hoc fecerunt arbitramur ueniam dari a Deo". No ha de ser confundida la sencillez con la 'simplicidad' de los que se confunden por haber sido engañados, cf AH 1,9,4 (SC 264**, p. 146). 
y Cristo corresponde, de igual modo, el intercambio entre la simplicidad en Cristo (2 Cor 11,3: "me temo que como la serpiente sedujo a Eva con astucia, vuestro modo de pensar se vicie abandonando la sinceridad y fidelidad a Cristo") y la del cristiano.

Ireneo da un paso más, corroborando la posibilidad de la simplicidad del Espíritu en los creyentes, y muestra cómo la paloma es imagen de la Virgen. "Se comprende por lo mismo que Ireneo, sensible a la antítesis entre la simplicidad columbina (cf. Mt 10,16), atribuible a todo lo inspirado por el Espíritu de Dios, y la astucia serpentina inherente al espíritu diabólico, no acabe de trazar las fronteras entre lo mariológico y lo cristológico"28.

Maria representa la sencillez de la Verdad o del Espíritu de Dios, sencillez que se contrapone a la astucia de la serpiente genesiaca. Maria con la sencillez de la paloma se atiene a la palabra de Dios. La simplicidad - escribe A. Orbe ${ }^{29-}$ está en función de la inteligencia simple, literal, de la Palabra de Dios (oral o escrita). María Virgen es imagen de la sencillez del que poseído por el Espíritu Santo se le comunica la simplicidad del mismo Espíritu, sencillez que triunfa de la astucia del espíritu maligno".

Pero la actitud del apóstol y su conducta en sencillez, y de los que siguen sus huellas, no se reduce a una mera actitud y actuación humana sino que refleja la realidad de Dios. S. Ireneo, en la antípodas de la gnosis, "no ve el modo de urgir las analogías de la actividad intelectual e incorpórea del alma humana con la divina. La simplicidad absoluta de Dios se lo prohíbe" 30 . La simplicidad absoluta de Dios invita al aprecio de la vivencia apofática por parte de los transmisores de la Palabra. El respeto a la Palabra de Dios y sobre Dios impone una sagrada cautela que tiene como pórtico la sencillez. Dios-Palabra-Verdad una única realidad

${ }^{27} \mathrm{AH} \mathrm{V}, 19,1$ (SC 153**, p. 250): "Adhuc enim protoplasti peccatam per correptionern prirnogeniti emendationem accipiens, et serpentis prudentia deuicta in columbae simplicitate (akeraióteti) uinculis autem illis resolutis per quae alligati eramus mortí". Cf A. Orbe (Teología de San Ireneo..., II, p. 282) propone afeleia como término usado por Ireneo y no el indicado por Rousseau. ofeleia escondería una referencia a Hech 2,46: "Y día por día, asiduos en asistir unánimemente al templo y partiendo el pan en sus casas, tomaban el sustento con regocijo y sencillez (simplicitate (afeloteti)) de corazón”.

28 A. Orbe, Teología de San Ireneo..., o.c., II, pp. 281-282.

29 Cf A Orbe, Teología de San Ireneo..., o.c., II, pp. 282; cf E. Romero, El influjo de la investigación patrística postconciliar en la Mariología, Compostellanum 39 (1994) 105-121.

30 A. Orbe, Teología de San Ireneo..., o.c., II, pp. 664-665. 
tan estrechamente unida que sólo desde la sencillez nos podemos aproximar a ella.

El Padre de todas las cosas está muy lejos de las disposiciones y pasiones a las que vivimos esclavizados los hombres. Él es simple, no compuesto $^{31}$. La simplicidad de Dios permite respetar el misterio y la sencillez con la que se debe exponer el mensaje, garantiza el que nos mantengamos en el mismo misterio y no lo fragmentemos. El misterio está hermanado con la sencillez mientras que la complejidad provoca la atomización del misterio. El ministerio de la Palabra está al servicio del misterio, lo custodia, lo respeta y lo transmite. Rota la simplicidad desaparece el ministerio y se anula el misterio.

Por ello el mensaje sencillamente expuesto mira a los sencillos y a los que no siéndolo se hacen. El Evangelio es para los sencillos y el mensaje de conversión conlleva volverse a la sencillez. Nada hay más opuesto a la predicación de la Magna Iglesia que la de los hombres falsos que engañan perversamente y son hipócritas - los discípulos de Valentín- que esclavizan a los comunes y eclesiásticos presentando a la multitud sus discursos con lo que llegan a confundir a los sencillos ${ }^{32}$. El peligro de los convertidos es que se vuelvan a la doblez, al equívoco. El ministerio en simplicidad está orientado a encaminar hacia la sencillez de la verdad a los extraviados por la equivocidad.

Los apóstoles, y sus seguidores, es decir los servidores del Verbo de la verdad (Lc 1,2), exhortaron a huir de aquellos que hablan de seducir y arrastrar a los simples, a los sencillos ${ }^{33}$. Los segundos, los amigos de la doctrinas y vida complejas- no se contentan con no aceptar lo creatural la sencillez- sino que arruinan a los demás, a los sencillos. La labor de los primeros edifica con la sencillez, la de los segundos destruye con la complejidad. Los primeros, por no ser receptores de otras doctrinas (por no ser amigos de

31 AH 11,13,3 (SC 294**, p. 114): "Multum enim distat omnium Pater ab his quae proueniunt hominibus adfectionibus et passionibus, et simplex et non compositus..."; (no conservamos el texto griego).

32 SH III,15,2 (SC $211^{* *}$, pp. 276-278): "Hi enim ad multitudinem propter eos qui sunt ab Ecclesia, quos communes et ecclesiasticos ipsi dicunt, inierunt sermones, per quos capiunt simpliciores (tón akeraión) et illiciunt eos, simulantes nostrum tractaturn, uti saepius audiant".

$33 \mathrm{AH}$ IV, pref. 3 (SC 100**, p. 386): "In eo igitur qui ante hunc est liber ostensa est de his omnibus sententia Apostolorum, quoniam non solum nihil tale senserunt qui ab initio speculatores et ministri fuerunt Verbi (Lc 1,2) veritatis, sed et praedicauerunt nobis fugere hujusmodi sententias, Spiritu prouidentes eos qui seducturi erant simpliciores (tous akeraíous)”. 
la complejidad) cuidaron mucho estar de parte de los sencillos. El continuador de la misión de los apóstoles, el constituido en el ministerio debe sentir lo que los primeros discípulos, pero además debe negarse a ser receptor de doctrinas marcadas por la complejidad para no arrastrar a los sencillos.

La exposición de la doctrina es cometido del ministerio, pero no lo es menos el ofrecer la oblación de la Iglesia que consiste en ofrendar a Dios los dones de la creación. En palabras de Ireneo, la demostración de la predicación apostólica no se puede comprender independientemente de la oblación. La administración de la Palabra es en sí misma una ofrenda en la que están incluidos los dones de la creación. Dios instituye la nueva oblación para glorificar al que la ofrece, es decir, a la Iglesia, dado que el que ofrece es glorificado personalmente en lo que ofrece si llega a ser acogido su don. Al igual que el hombre creado es glorificado cuando es llevado a su plenitud, a la resurrección, y podemos decir que el hombre es la gloria de Dios, así también en el don ofrecido se manifiesta el afecto glorificando al que es amado en el don. El constituido en el ministerio de la Palabra y de la oblación refleja, en su mismo servicio, el evento transformador que acontece en él. La Palabra comunicada y la ofrenda realizada son signos de la obra de Dios. En suma, el ministerio es cauce transmisor de la irrupción de Dios en la creatura.

Mas a Dios han de ser ofrendadas las primicias de la creación con simplicidad e inocencia. S. Ireneo pone en conexión la sencillez con que ha de ser administrada la Palabra con la sencillez e inocencia con que ha de ser ofrecida la oblación instituida por Cristo que es la nueva oblación, una vez aceptada por Dios, que glorifica a la Iglesia. La sencillez, la inocencia, en el ministerio de la Palabra es la pedagoga para enseñarnos la fraternidad. Simplicidad y fraternidad son exigencias del seguimiento apostólico que tienen como consecuencia la oblación agradable al Padre.

En efecto, la ofrenda querida por Dios es el don de la reconciliación con el hermano (Mt 5,23-24: "si mientras llevas tu ofrenda al altar te acuerdas de que tu hermano tiene queja de ti, deja la ofrenda delante del altar, ve primero a reconciliarte con tu hermano y después ve a llevar tu ofrenda"). Pero la condición previa para alcanzar la reconciliación es la sencillez y la inocencia. El hombre que ofrece los dones que le son concedidos gratuitamente recibe, con la aceptación, el honor que proviene de Dios $^{34}$. Ireneo da a entender que la sencillez e inocencia posibilitan la aceptación del hermano y de la ofrenda. Aúna la fraternidad a la sencillez. 
De este modo Dios, desde el inicio, aceptó con agrado los dones de Abel porque ofrendaba su oferta con simplicidad y justicia (= inocencia) frente a Caín que los ofrecía con envidia y malicia. Caín provocaba la división. La sencillez unifica el interior con lo exterior ${ }^{35}$. De esto resulta que tanto la exposición de la Palabra como el culto verdadero si no se apoya en la sencillez es germen de mentira, alimenta la separación entre teoría y vida y conduce a un culto vacío en la pura exterioridad. La sencillez es la tierra buena en la que fructifica la unidad y no consiente la semilla de la división, La simplicidad es la tierra nueva, es la plantación en la que Dios ha depositado todo lo que él quiere para la humanidad nueva.

La Iglesia, de igual modo que Abel, es la única que ofrenda en simplicidad, dado que su don - por hacerlo agradecida al confesar que todo es gratuitamente recibido- cuenta ante Dios como sacrificio puro. La sencillez es actitud propia que nace del ánimo puro, de la fe sincera, de la esperanza firme y del amor ardiente. Sólo la Iglesia ofrenda puramente y con verdad la Eucaristía a partir de las primicias de la Creación ${ }^{36}$, a saber: ofrece con agradecimiento lo que procede de la creación, el pan y el vino que indican la realidad creatural acompañados en todo momento por el Creador y ahora transformados por la aceptación. Es que la sencillez corre paralela al agradecimiento. El ofrecimiento de un don sin sencillez no es ofrenda agradecida; es interesada y egoísta por no fiarse de Aquel a quien se ofrece.

Los ejemplos bíblicos corroboran cómo la simplicidad es la tierra elegida para que fructifiquen las dádivas de Dios. Así las hijas de Lot son excusadas, al igual que Eva, por su simplicidad e inocencia ${ }^{37}$ La enseñan-

34 AH IV,18,1 (SC 100**, p. 596): “...quod in omni simplicitate (haplóteti) et innocentia Dominus uolens nos oferre praedicauit dicens: OMt 5,23-24)".

35 AHIV,18,3 (SC 100**, p. 598-600): “Ab initio enim respexit Deus ad munera Abel, quoniam cum simplicitate (haplótetos) et justitia offerebat; super sacrificium autem Cain non respexit, quoniam cum zelo et malitia quae erat aduersus fretrem diuisionem habebat in corde, quemadmodum occulta ejus arguens Deus ait: (Gen 4,7)..."

36 AH IV,18,4 (SC 100**, p. 606): “Quoniam igitur cum simplicitate (haplótetos) Ecclesia offert, juste munus ejus purum sacrificium apud Deum deputatum est..."

37 AH IV,31,2 (SC 100**, p. 790): "Illae quidem filiae secundum simplicitatem (ekeraióteta) et innocentiam putantes uniuersos homines periisse, quemadmodum Sodomitas, et in uniuersam terram iracundiam Dei subuenisse, dicebant haec. Quaepropter et ipsae excusabiles sunt, arbitrantes se solas relictas cum patre suo ad conseruationem generis humani, et propter hoc circumueniebant patrem". 
za del obispo de Lyón subraya que la dispensación de Dios cuenta más que los actos de los hombres ${ }^{38}$, y que la sencillez que acompañan las acciones refleja más el modo de actuar Dios, quien hace todo conforme a su bondad simplicísima, y mostrándonos que no es envidioso y sí dadivoso. La dádiva va acorde con la bondad simplicísima. De esta forma el que sirve en la administración de la Palabra y en la ofrenda cultual imitará la actuación de Dios, que se nos da por su amor simplicísimo ${ }^{39}$.

Ahora bien la sencillez, es un don, propio de Dios y de su Santo Espíritu que es comunicado a los bautizados (en el Jordán), a los creyentes, y sin esa sencillez no se puede acoger la Palabra ni transmitirla. El Espíritu, y acción, que le es comunicado a Maria es el mismo Espíritu que se comunica a los apóstoles para ser servidores de la Palabra. Y en María y en los apóstoles se hace visible la sencillez como don del Espíritu. Una actitud que no fuera la de la sencillez no tiene cabida en la historia del designio salvífico de Dios.

Los términos haplós, apanourgos, akéraios, aféleia (simpliciter simplex, simplicitas) permiten a Ireneo presentar aspectos esenciales de la vida cristiana en general y del ministerio apostólico en particular. Cabría el haber perseguido, paso a paso, los versos escriturísticos comentados por Ireneo en los que desvela la simplicidad inherente al ministerio cristiano. Para evitar la prolijidad nos contentamos con haber señalado las principales indicaciones presentes en la tradición acogida por S. Ireneo y que permanecerá en los autores que se pueden adscribir a la escuela asiática y que en buena parte participan del mismo pensamiento: la escuela africana y exegetas de la Panonia, concretamente los escritores de la iglesia de Pettau. Asiáticos, africanos y parádosis equidistantes de los griegos y latinos denuncian un pensamiento muy similar acerca del ministerio (resp. la concepción de la salvación) e indican que son testigos de una muy antigua tradición común.

38 Cf. A. Orbe, Los hechos de Lot mujer e hijas vistos por San Ireneo (Adu.Haer. IV,31,1,15/3,75), Gregorianum 75 (1994) 37-64. La figura de Lot tiene en la obra del obispo de Lyón una importancia capital.

${ }^{39} \mathrm{AH}$ IV,38,4 (SC 100**, p. 958): "Nos autem imputamus ei quoniam non ab initio dii facti sumus, sed primo quidem homines, tunc demum dii, quamuis Deus secundum simplicitatem (akéraion) bonitatis suae hoc fecerit, en quis eum putet inuidiosum aut impraestantem..." 


\section{El peligro de orgullo de los adornados de "sobre-eminente ministerio"}

Si la sencillez es una característica del ministerio, uno de los frutos de la sencillez es la paciencia, la ausencia de orgullo y huir de tentar a Dios. De ahí que los administradores de la Palabra, los adornados de sobre-eminente ministerio (diakonia) y los situados en la cima de los carismas deben saber esperar con paciencia, ser humildes y no enorgullecerse ni tentar a Dios:

"En cambio, a los redimidos nos enseñó mediante el mismo precepto: a esperar con paciencia, cuando hambrientos, el manjar otorgado por Dios; y a no enorgullecernos ni tentar a Dios, cuando situados en la cima de los carismas todos, por confiar en las obras de justicia o por vernos adornados de sobreeminente ministerio (supereminentia ministrationis). Al contrario, enseñonos a nutrir en todo sentimientos humildes, y tener siempre a la mano lo de (Deut 6,16; Mt 4,7): No tentarás al Señor tu Dios. Lo mismo enseñó el Apóstol al decir (Rom 12,16): No teniendo sentimientos de altivez, sino sintiendo con lo humilde. Enseñonos por último el Señor a no dejarnos sorprender por las riquezas y por la gloria mundana y por la fantasía presente. A entender, por el contrario, que conviene adorar al Señor tu Dios y a Él solo servir. Y a no creer a quien prometió con falsía lo que no es suyo, diciendo (Mt 4,9): Todo esto te lo daré, si cayendo me adorares" 40 .

Supereminentia ministrationis (diakonias) puede hacer referencia a la dignidad y alteza del ministerio, considerándolo como un oficio alto en la jerarquía de Iglesia. En este sentido, el texto ireneano aludiría a que los constituidos en el ministerio debían estar siempre atentos a no engreírse. El enorgullecimiento sería una peligrosa tentación de los que estaban al servicio de la Palabra y de la mesa.

\footnotetext{
${ }^{40} \mathrm{AH} \mathrm{V}, 22,2$ (SC $153^{* *}$, p. 282): "Nos autem solutos per ipsum praeceptum docuit esurientes quidem sustinere eam quae a Deo datur escam, in sublimitate autem positos uniuersi chariatis nel in operibus justitiae confidentes uel ministrationis (diakonias) supereminentia adornatos nequaquam extolli neque temptare Deum, sed humilia sentire in omnibus et prae manu habere: Non temptabis Dominum Deum tuum, quemadmodum et Apostolus docuit, Non alta -dicens- sentientes. sed humilibus consentientes; nec diuitiis nec gloria mundana neque praesenti phantasia capi, scire autem quoniam Dominum Deum tuum adorare oportet et ipsi soli semire; et non credere ei qui falso promisit ea quae non sunt sua, dicens: Haec omnia tibi dabo, si procidens adoraueris me”. Cf. A. Orbe, Teología de San Ireneo..., 11, pp. 440-461.
} 
No es ésta la única lectura que cabe hacer de la "sobreeminencia del ministerio", pues a la luz de la Epideixis ${ }^{41}$ la "supereminentia ministrationis" puede muy bien referirse a servidores supereminentes, es decir, a los ángeles que -según Ireneo- están al servicio de Dios y de los hombres. No obstante, "Ireneo -escribe A. Orbe ${ }^{42}$ - se refiere, en su aplicación actual, a los simples fieles; no a los constituidos en dignidad (cf. 1 Tim 2,2)". Poniendo en relación AH V,22,2 con AH 11,35,4 se puede colegir "que uno no tan iluminado como Cristo ni por Cristo se habría lanzado por los aires, tentando a Dios, como quien exige el ministerio de los ángeles para no lastimarse el pie". A tenor del ejemplo del Salvador, "Cristo -continúa A. Orbe- no tentó a Dios con la alteza del ministerio (Angélico) que le ofrecía el diablo"43, del mismo modo los cristianos no hemos de tentar al Creador por la alteza de los siete Espíritus puestos al servicio de la salvación. Ireneo advierte que nadie por el ministerio desprecie o sea altivo con los demás. Para Ireneo la división de ministerios (cf. 1 Cor. 12,4-7) 44 $^{4}$ debe responder a la diakonía del Señor. Cada ministerio, el concedido a cada cual, debe mirar a la utilidad de todos. Orbe se pregunta si Ireneo no pensaría $(\mathrm{V}, 22,2)$ en la parábola del Buen Samaritano, en el "levita" y el "sacerdote" (cf. Lc 10,31-32). En cualquier caso, el pensamiento de Ireneo, señala que el cristiano, constituido o no en el ministerio ordenado, debe apartarse del peligro del orgullo; se le requiere no estar al servicio de uno mismo sino de los demás, sin caer en la tentación de rechazar lo humano y sus limites.

La principal obra de S. Ireneo, considerada como un servicio ministerial, es el Aduersus haereses. En ella se encierran pinceladas claramente autobiográficas. En la apertura de la misma ${ }^{45}$, advierte que prestó un servicio exponiendo los sistemas de la falsa gnosis para presentar, asimismo, la auténtica tradición. Y lo expuesto se pone a disposición del amigo que se lo demandó. Los que reciben la obra de Ireneo la deben poner al servicio de los demás según la gracia dada por el Señor. Es difícil poner nombre concreto y saber quién es el amigo a quien se dirige el obispo de Lyón.

\footnotetext{
${ }^{41}$ Epideixis 9.11.12.

42 Teología de San Ireneo..., o.c., II, p. 444.

43 Cf. A. Orbe, Ibid.

${ }^{44} \mathrm{Cf}$. AH IV,20, 6.

45 Cf. AH I, pref.. 3.
} 
A. Orbe ${ }^{46}$ afirma que puede ser un obispo amigo, obispo también como Ireneo, puesto al servicio de la palabra. En este caso el obispo es el servidor de todos según la gracia donada por el Señor ${ }^{47}$.

Ireneo refiere que un aspecto importante del ministerio eclesial es sentirse sabedor de los dones recibidos del Señor. Dado que gratuitamente los recibe gratuitamente los distribuye o ministra (cf. Mt 10,8) ${ }^{48}$. Cuando se tiene presente la gratuidad se puede dirigir a todos y no solo a unos pocos. Los gnósticos como son receptores de tan grandes misterios que sólo los que pueden dar grandes compensaciones son dignos de recibirlos tienen razón en pensar en unos pocos ${ }^{49}$. Desde la gratuidad el ministerio es para todos porque es consciente de que no es algo propio sino recibido: "Porque como gratuitamente lo ha recibido de Dios, gratuitamente también lo distribuye" 50 .

Mucho dista este servicio, el de Ireneo y el de su amigo, del servicio que se presta - tal como apunta irónicamente el obispo de Lyón- a las especulaciones de Marcos Valentiniano ${ }^{51}$. El ángel, el ministro, que está al servicio del adversario, del diablo, le ministra entregándole las almas para que las encierre en un cuerpo ${ }^{52}$. Los ángeles del Pléroma son a imagen de los ángeles del Creador según lo profetizado en Dan 7,1053. Las utilizaciones, en Ireneo, del verbo ministrare por parte de los sectarios marcan la diferencia con la concepción eclesiástica del servicio o ministerio. No

46 Teología de San Ireneo..., o.c., I, pp. 32-33.

${ }^{47} \mathrm{AH}$ I, praef. 3 (SC $264 * *$, p. 26). "Et quemadmodum nos elaborauimus, olim quaerenti tibi discere sententiam eorum, non solum facere tibi manifestam, sed et subministrationem dare, uti ostenderemus eam falsam, sic et tu efficaciter reliquis ministrabis (diakonéseis) secundum gratiam quae tibi a Domino data est, ut iam non abstrahantur homines ab illorum suadela, quae est talis".

48 AH II,32,4 (SC $294^{* *}$, p. 342): "quemadmodum enim gratis accepit, gratis et ministrat (diakonei)".

49 AH I,4,3 (SC 264 **, p. 68): “... sed solos illos qui etiam grandes mercedes pro talibus mysteriis praestare possunt. Non enim iam dicunt similia illis de quibus Dominus noster dixit: Gratis accepistis, gratis date (Mt 10,8)"”.

${ }^{50} \mathrm{Cf}$. AH II,32,4.

${ }^{51} \mathrm{Cf}$. AH I, pref. 3.

52 AH I, 25,4 (SC 264**, p. 340): "Et hunc dicunt esse primum ex mundi fabricatoribus, et illum altero Angelo, ei qui ministrat ei, tradere tales animas, uti in alia corpora includat".

${ }^{53}$ AH II,7,4 (SC 294**, p. 74): "Deinde autem, cui sint multi et innumerabiles circa Factorem Angeli, quemadmodum omnes confitentur prophetae dena milia denum milium adsistere ei et multa milia miliorum ministrare ei (Dan 7,10$)$ ". Sería de estudiar la relación entre la concepción del ministerio y la angelología. 
consiste concordar en la palabra sino en el sentir lo mismo. La diferencia entre gnosis y la auténtica revelación, y también entre ministerio y ministerio, está no en las mismas palabras sino en que sentimos distinto.

El análisis de los términos diakonía y afines permiten adentrarse en el horizonte de la teología ministerial del obispo de Lyón. Salta a la vista que Ireneo piensa en todo el pueblo de Dios, en el bautizado, al aludir a los múltiples servicios con que el Espíritu adorna a su Iglesia. El ejercicio del ministerio en simplicidad especificaba un estilo de ministerio contrapuesto a las concepciones gnósticas. La referencia inequívoca es el Hijo encarnado cuyo servicio, ministerio, al Padre mira directamente a la mediación en la creación y en la salvación y en última instancia a la comunicación del Espíritu a la carne. Todo ministerio eclesial no puede apartarse de este núcleo fundamental

\section{El ministerio del Hijo y del Espíritu y el ministerio eclesial}

Ireneo cimienta la antropología en la cristología. Y la teología del ministerio tiene su referente en la vida trinitaria, en el ministerio del Verbo y del Espíritu Santo. Los verbos, diakoneô, leitourgeô e hipourgéo y sus derivados, que recurren en el Adversus haereses, nos indican las diversas perspectivas y matices del ministerio cristiano. Ireneo -acorde con los escritos neotestamentarios, especialmente los paulinos- no se refiere sólo al ministerio ordenado sino a todo servicio que puede prestar el creyente. La ministratio servicio de los hombres, se refiere a la vida cotidiana:

"En efecto, ¿de dónde vienen las casas en que habitamos y los vestidos con que nos cubrimos y los objetos que usamos y lo demás todo al servicio de nuestra prolongada vida...?"54.

La utilización del término ministerium (diakonía) ${ }^{55}$ en los escritos ireneanos es extensivo a todos los cristianos y no solamente a los constituidos en el servicio o ministerio de la Palabra.

Es en la teología trinitaria donde aparece con toda virtualidad la teología del ministerio. Este refleja la administración divina. El Hijo es medi-

\footnotetext{
${ }^{54} \mathrm{AH}$ IV,30,1 (SC 100**, p. 772): "Unde enim domus in quibus habitamus et uestimenta quibus induimur et uasa quibus utimur et reliqua omnis ad diuturnam uitam nostram ministratio (diakonia).

55 La mayoría de las referencias a Minister y ministri en la obra de San Ireneo pertenecen a textos bíblicos.
} 
da del Padre y, de igual forma, las obras de Padre y del Hijo son limitadas (ya sea la Ley, ya sea Jerusalén) conforme a la medida de la disposición divina ${ }^{56}$. Hay una relación entre el ministerio y la limitación que proviene de la administración divina. La ministerialidad denuncia la 'limitación divina' en favor del hombre. Es por todos conocido que la dimensión ministerial del Hijo y del Espíritu en la existencia trinitaria es uno de los aspectos más hondos del pensamiento teológico del obispo de Lyón:

"Así pues, mediante esta ordenación (o proceso) y tales fases y disciplina, el hombre hecho y plasmado es constituido a imagen y semejanza del Dios Increado; el Padre lo tiene a bien y ordena; el Hijo sirve y da forma; el Espíritu nutre y da incremento; el hombre adelanta y llega a lo perfecto, a saber hasta allegarse al Increado, porque perfecto es el Increado, y éste es Dios"57.

El Padre lo tiene a bien y ordena, el Hijo sirve y da forma y el Espíritu Santo nutre y da incremento. Lo propio del Verbo es la diakonia y la demiurga es decir, la ministerialidad: servir y dar forma. El servicio está abocado a dar forma a lo que tuvo a bien la disposición (economía) creadora del Padre. El Espíritu alimentará y llevará a buen término el servicio prestado por el Hijo. No hay creación sin ministerio del Hijo ni 'Pascua de la creación' sin el Espíritu Santo. Es de subrayar los términos hipourgountos y plássontos, la cercanía de lo diaconal a lo plástico y el papel que Ireneo le asigna a la diakonía del Hijo en relación a la creación del cosmos y a la plasmación del hombre. El ministerio (diakonia) primero corresponde al Hijo y al Espíritu Santo. El Hijo, como diácono y ministro del Creador, fabrica el mundo, modela -aun más, plasma- al hombre y lleva a término la dispensación de la salvación humana. El ministerio del Verbo está determinado por la asistencia al Padre y por conducir a la perfección a la obra del Padre-Creador.

56 AH IV,4,2 (SC $100 * *$, p. 420): "Et bene qui dicit ipsum immensum Patrem in Filio mensuratum: mensura enim Patris Filius, quoniam et capit eum. Quoniam autem temporalis erat illorum administratio (diakonia), Esaias ait...

57 AH IV,38,3 (SC 100**, pp. 954-956): "Per hanc igitur ordinationem et hujusmodi conuenientiam et tali ductu factus et plasmatus homo secundum imaginem et similitudinem constituitur infecti Dei, Patri quidem bene sentiente et jubente, Filio uero ministrante (hipourgountos) et formante (plássontos), Spiritu uero nutriente et augente, homine uero paulatim proficiente et perueniente ad perfectum, hoc est proximum infecti fieri: perfectus enim est infectus, hic autem est Deus". Cf A. Orbe, Teología de San Ireneo..., IV, ad loc. 
El obispo de Lyón se mantiene lejos de las proposiciones gnósticovalentinianas y marcionitas. Ministerio, diakonía del Verbo, creación del cosmos y plasmación del hombre son inseparables. El ministerio del Verbo mira a la plasmatio Hominis y tanto no se desatiende de lo creatural que quien plasma (formante) al hombre es el Hijo que sirve (ministrante). Si se observa el matiz del término hipourgountos (= el útil, el favorable, el que sirve) se puede colegir que lo más favorable al hombre, el que más le sirve, es el Verbo por posibilitarle ser lo que es y lo que podrá ser. La creatura viene a la vida y crece por la mediación del Verbo. El verdadero ministerio, el servicio (ministrans; hipourgesas) de Jesús, dice relación al servicio al querer creatural y salvífico del Padre. Jesús es el cumplimiento y perfección de todo vaticinio y, al mismo tiempo, es el diácono de la Voluntad del Padre.

El Hijo, por ser ministro del Padre, está a Él asociado, desde el primer momento, a la obra de la creación y a la de la salvación. La gran e inefable ayuda al Padre se la presta el Verbo. El Padre es asistido, ministrado, en todas las cosas por sus Manos ${ }^{58}$, por el Verbo y el Espíritu, a los que le sirven todos los ángeles. El Padre, de nadie necesita, todo lo lleva a cabo y dispone por gratuidad. El Hijo asiste al Padre ${ }^{59}$ y por su ministerio fontal él se da a conocer a los hombres para que éstos conozcan al Padre. El ministerio por excelencia, pues, toca al Hijo, origen y fuente de todo ministerio:

"Estas cosas en efecto las disponía el Hijo, el Verbo de Dios, desde el principio, porque el Padre no requería ángeles para llevar a cabo la creación o para formar al hombre, en cuyo beneficio se hacía la creación. No le faltaban ayudas para configurar lo creado o disponer los negocios relativos al hombre. Tenía abundante e inenarrable servicio ('copiosum et inenarrabile ministerium'). Pues para todo le asiste su prole y su ornato, a saber, el Hijo y el Espíritu, el Verbo y la Sabiduría, a quienes sirven y están sujetos los ángeles todos"60.

58 Cf. A. Orbe, Las manos de Dios en Introducción a la Teología de los siglos II y III. Roma 1987, I, pp 230-254.

${ }^{59} \mathrm{AH}$ IV,7,4 (SC 100**, p. 464): “... neque rursus indigente ministerio (diakonias) ad fabricationem eorum quae facta sut (et) dispositionem eorum negotiorum quae secundum hominem erant, sed habente copiosum et inenarrabile ministerium (diakonian); ministrat (diakonei) enim ei ad omnia sua progenies et figuratio sua, hoc est Filius et Spiritus, Verburn et Sapientia, quibus seruiunt et subjecti sunt onmes angeli".

60 AH IV,7,4 (SC 100**, p. 462): "Haec enim Filius qui est Verbum Dei ab inítio praes- 
Por medio del ministerio, el Hijo lleva a cabo la voluntad del Padre en todas las $\operatorname{cosas}^{61}$. Ireneo remite al ministerio fundante de Cristo su relación con el querer del Padre, raíz de todo ministerio y servicio que tiene como fin dar a conocer a Dios y comunicar a los hombres que ver a Dios es la salvación de la humana carne. Sin el ministerio del Hijo no podríamos pronunciar el hermoso axioma ireneano: "Porque la gloria de Dios es el hombre dotado de Vida; y la Vida del hombre es la visión de Dios"62. El ministerio conlleva la marca de la visibilidad -aspecto fundamental en la antropología y en la cristología- y que no podrá estar ausente en el ejercicio del ministerio cristiano; la fuerza del ministerio estriba en plasmar el designio del Padre para la humanidad y el cosmos.

Los gnósticos emplean similares términos para indicar como ministrante a la facultad intelectiva que produce, sirve (organiza) y gobierna ${ }^{63}$, pero desprecian la dimensión de visibilidad inherente a la diakonía o ministerio del Hijo. Sin embargo, no se oculta la relación de la especulación gnóstica con la teología eclesiástica en lo relacionado con la teología del ministerio o asistencia del Verbo al Padre. Si en el mismo corazón de la teología -esp. en las especulaciones trinitarias- los eclesiásticos (no digo los ortodoxos, respetando la opinión de los que piensan hay que superar la dialéctica ortodoxia-heterodoxia ${ }^{64}$.) siguieron caminos iniciados y explorados por los gnósticos, nada tiene de extraño que también en lo relacionado con la teología del ministerio haya interrelaciones entre

truebat, non indigente Patre angelis uti faceret conditionem et formaret hominem propter quem et conditio fiebat, neque rursus indigente ministerio (diakonias) ad fabricationem eorum quae facta sunt (et) ad dispositionem eorum negotiorurn quae secundum hominem erant, sed habente copiosum et inenarrabile ministerium (diakonian): ministrat enim ei ad omnia sua progenies et figuratio sua, hoc est Filius et Spiritus, Verbum et Sapientia, quibus seruiunt et subjecti sunt omnes angeli". Tomo la versión castellana del AH IV de A. Orbe, Teología de San Ireneo. Traducción y Comentario al Libro IV del "Adversus haereses", B.A.C., Madrid 1997.

61 AH IV,20,6 (SC 100**, p. 642): "alii uero aduentum Domini et eam quae est ab inítio administrationem (diakoniam), per quam perfecit uoluntatem Patris quae est in caelis et quae est in terris".

${ }^{62}$ Cf. AH IV,20,7 (SC 100**, p 648) Cf. A. Orbe, Gloria Dei vivens homo. Análisis de Ireneo, adv haer. IV,20,7. Gregorianum 73/2 (1992)n 205-268.

63 AH II,13,1 (SC 294**, p. 110): “... et in uerbum coemissae, sensu manente intus et condente et administrante et gubernante libere et ex sua potestate, quemadmodum et uult, quae praedicta sunt".

${ }^{64}$ Cf M. Simonetti, Ortodossia de Eresia tra I e II secolo, Rubbettino, Messina 1994. 
unos y otros. Véase, a modo de ejemplo, la función ministerial del Verbo como diácono en el ámbito trinitario.

El Dios imaginado por los gnósticos, al que nadie puede conocer, que no se comunica con el género humano y que no administra las cosas terrenas, es el Dios de los epicuros que a nadie sirve ni para sí ni para los demás, es decir que no es providente para con nadie ${ }^{65}$. Este Dios no tiene por qué disponer de mediación o ministerio alguno. La incomunicabilidad de Dios confirma la no necesidad del ministerio, la anulación de éste arrastra a la negación de la providencia. Por el contrario, el Dios que administra es el que se comunica, el que se da a conocer y salva. El ministerio mira a dar a conocer y salvar en visibilidad, en la historia, en carne en contraste con el pensamiento mítico-gnóstico. La distancia entre el ministerio de la visibilidad en función de dar a conocer la salvación "en la carne" y el ministerio en la esfera de la invisibilidad (gnóstico), sitúa al cristianismo en las antípodas de la mitología. El ministerio del Verbo, y en consecuencia, todo ministerio en él arraigado es un grito en pro de la visibilidad, de la encarnación.

Lo propio del ministerio del Hijo es revelar al Padre ${ }^{66}$. El Dios que no es directa e inmediatamente conocido por el hombre se da a conocer solamente al Hijo y por medio de éste a quienes el Hijo se lo quiera dar a conocer. La administración del Hijo, el ministerio (intervención), es querida por el Padre y es asimismo necesaria la mediación. Ocultar el ministerio es propugnar la eliminación de la mediación y, en última instancia, de la intervención de Dios en la historia.

Dios Padre se da a conocer con la eficacia del Espíritu, la diakonia del Hijo, la aprobación del Padre y la consumación del hombre para su salvación. La voluntad del Padre, desde el principio, se lleva a cabo por el ministerio del Señor ${ }^{67}$. Todo subsiste por la providencia del Padre y por su

65 AH III,24,2 (SC 211**, p. 478): “... ut magnum Deum putentur aduenisse quem nemo possit cognoscere, humano generi (non) communicantem nec terrena administrantem (diakounta), Epicuri uidelicet inuenientes Deum, neque sibi neque aliis aliquid praestantem, hoc est nullius prouidentiam habentem".

66 AH IV,7,3 (SC 100**, pp. 460-462: "Hunc ergo recte ostendimus a nemine cognosci nisi a Filio et quibuscumque Filius reuelauerit; reuelat autem omnibus Filius quibus uelit cognosci Pater, et neque sine bona uoluntate Patris neque sine administratione (diakonias) Filii cognoscat quisquam Deum".

${ }^{67}$ AH IV,20,6 (100**, pp. 642-644): “....alii uero aduentum Domini et eam quae est ab initio administrationem (hipourgían), per quam perfecit uoluntatem Patris quae est in caelis et quae est in terris". 
imperio todas las cosas son administradas ${ }^{68}$. Sin embargo el imperio del Padre está en la raíz de todo ministerio.

La insistencia y la importancia concedida por Ireneo al ministerio del Verbo está muy presente en los antecedentes asiáticos. Jesús es para S. Ignacio de Antioquia ${ }^{69}$ aquel en el que refulge la diakonia, para Policarpo $^{70}$ el "diacono de todos", y para Ireneo Cristo es el que sirve al Padre:

"Pues las cosas anunciadas por el Creador en forma similar mediante todos los profetas, Cristo las llevó a cumplimiento en el fin (de los tiempos), como quien servía al querer de su Padre y consumaba la humana economía"71.

El ministerio fontal reclamará a todo ministerio que se apoye en él, que favorezca a ser el hombre lo que el Padre ha querido que sea. El ministerio del Hijo es el que el Padre que tiene para servir a las economías, a la salvación porque el Verbo ha sido el único que puede servir a Dios sin ofensa. También David y Salomón, a la sombra del Verbo, cuando sin ofensa sirven a Dios cooperan a las disposiciones divinas y son merecedores de alabanza:

"Según eso, cuando sin ofensa servía a Dios cooperaba a sus disposiciones, era objeto de alabanza" 72 .

Interesa subrayar la correlación sin ofensa/servir a Dios/ cooperar a las economías/glorificación. El fin del ministerio cristiano es conocer a Dios. Y nadie conocerá a Dios sin el beneplácito del Padre y sin la intervención (administración) del $\mathrm{Hijo}^{73}$. La ministratio Verbi se ejerce por el magiste-

68 AH IV,36,6 (SC 100**, p. 906): "Est autem hic Pater Domini nostri, cujus prouidentia constant omnia et jussu administrantur (dioikeitai) omnia”.

69 Cf Magn 6,1 (diakonian Iesou Christou) (FPt 1, p. 130); Tral. 3,1 (tous diakónous ós Iesoun Christón) (FPt 1, p. 140).

70 Cf Phil 5,2 (diákonos pánton) (FPt 1, p. 218).

71 AH V,26,2 (SC 153**, p. 332): “Ouae enim a Demiurgo praedicta sunt similiter per onmes prophetas, haec Christus in fine perfecit, ministrans (hipourgesas) Patris sui uoluntati et adimplens secundurn humanurn genus dispositionem". AH IV, 38,3 (SC 100**, p. 954): "Patre quidem bene sentiente et jubente, Filio uero ministrante (hipourgountos) et formante, Spiritu uero nutriente et augente...". Cf AH IV,20,6; IV,7,7. Cf A. Orbe, Teología de San Ireneo.... o.c., 1, p. 85 .

72 AH IV,27,1 (SC 1OO**, p. 736): “Cum ergo sine offensa seruiret Deo et ministraret (hiperetei) dispositionibus que tunc glorificabatur".

73 AH IV,7,3 (SC 100**, pp. 460-462): "Reuelat autem omnibus Fílius quibus uelit cognosci Pater, et neque bona uoluntate Patris neque sine administratione (diakonias) Filii cognoscet quisquam Deum". 
rio del $\operatorname{Logos}^{74}$, mediante el cuidado (hipourgia) permanente del Hijo. E1 Hijo, diácono y revelador del Padre, da a conocer al hombre las profecías, los carismas y sus ministerios, a modo de una melodía bien compuesta y armoniosa, en favor de los hombres ${ }^{75}$. Las enseñanzas del que está al servicio de la Palabra debe saber que aquéllas deben concordar con el magisterio del Señor, con el anuncio de los profetas, con la predicación y los preceptos de los apóstoles y con el ministerio de la Ley ${ }^{76}$. La ministratio, el servicio de la Ley es presentar la armonía existente entre el anuncio y el cumplimiento, entre la profecía y el Evangelio ${ }^{77}$.

Así como a los que vivieron según la Ley se les asignó una función sacerdotal y ministerial (sacerdotalem et ministerialem) ${ }^{78}$ y los sacerdotes podían cumplir sus ministerios en sábado en favor del pueblo. siguiendo así el espíritu de la ley ${ }^{79}$ de igual modo el ministerio sacerdotal es un servicio al pueblo al coincidir con el autentico espíritu de la ley.

"Los sacerdotes profanaban el sábado en el templo sin incurrir en falta... no eran reos porque, moradores del templo, ejercían ministerios dominicales, no seculares. Cumplían la Ley" 80.

No existe autentica diakonia, verdadero ministerio, fuera del espíritu de la Ley. El ministerio según la Ley y que se ejerce en favor del pueblo es el que merece el calificativo de auténtica liturgia. Al igual que las curaciones en sábado, el ministerio cultual mira a la curación y a la liberación de todos.

$74 \mathrm{AH} \mathrm{V}, 1,1$ (SC 153**, p. 18): “... secundum ministrationem (hipourgían) Verbí”. AH IV,38,3 (SC 100**, p. 954): "Filio uero ministrante et formante". Cf A. Orbe, Teología de San Ireneo..., o.c., II, p. 62.

75 AH IV,20,7 (SC 100**, p. 646): “... qui et uisiones propheticas et diuisiones charismatum et ministeria (diakonias) sua et Patris glorificationem consequenter et composite ostenderit humano generi apto tempore ad utilitatem".

76 AH II,35,4 (SC 294**, p. 264): "Quoniam autem dictis nostris consonat praedicati apostolorum et Domini magisterium et prophetarum adnuntiatio et apostolorum dictatio et legislationis ministratio...”. Cf A. Orbe, Teología de San Ireneo..., o.c., II, p. 444.

77 Cf. A. Orbe, Ibid.

78 AH III, 11,8 (SC 294**, p.168): "his uero qui in lege, sacerdotalem et ministerialem actus praebebat (hieratikén kai leitourgikén)

79 AH IV,8,2 (SC 100**, p. 468): "Non enim prohibebat lex curari homines sabbatis, quae et circumcidebat eos in hac die, et pro populo ministeria (leitourgia) jubebat sacerdotibus perficere, sed et mutorum animalium curationem non prohibebat".

${ }^{80}$ AH IV,8,3 (SC 100**, p. 476): "Quoniam, cum essent in templo, non saecularia sed dominica perficiebant ministeria (leitourgías), legem adimplentes, non autem praetereuntes legem... 
"La Ley no prohibía curar en sábado a los hombres. La misma que los circuncidaba ese día (cf. Jn 7,22-23) y ordenaba a los sacerdotes cumplir sus ministerios por el pueblo (en sábado), y tampoco prohibía cuidar de mudos animales (en ese día)" $"$.

El ministerio que se deja conducir por el espíritu de la Ley mira a curación del hombre. En efecto el sentido mediato del sábado que llena los días del ministerio sacerdotal de una forma continua está todo él referido al descanso definitivo del hombre en la mesa de Dios. Puede que Ireneo apunte el ministerio eucarístico aquí con miras al banquete, a la salvación, definitivo. Por eso el servicio a Dios, el ejercicio sacerdotal, exige la plena entrega por estar al servicio del único fin importante para el hombre. Requiere la mayor de las perseverancias. Fuimos estimados todo el día ovejas de sacrificio (cf. Rom 8,36; Salm 43,22), es decir, consagrados y sirviendo en todo a nuestra fe, perseverando en ella y alejados de toda avaricia, sin adquirir ni poseer tesoros en la tierra ${ }^{82}$.

El ejercicio sacerdotal reclama desprendimiento y dedicación absoluta. El ministerio guarda una relación entre perseverancia y dedicación total. La entrega parcial y no absoluta está abocada a considerar que la finalidad del ministerio tiene un alcance relativo para el hombre. Y, lo que es más importante, el abandono de todo supone la justicia, porque sólo los justos pueden esperar la herencia que es el Señor mismo, los que nunca profanan el templo (resp. el cuerpo) ni el sábado. Lo que la Estoa dice del sabio (que tenía rango sacerdotal) lo enseña Ireneo del justo.

"Los sábados, a su vez, enseñaban la perseverancia, por todo el día, en el servicio de Dios. Pues 'fuimos estimados - dice el apóstol Pablo (Rom 8,36; cf. Ps 43,22) - todo el día por ovejas de sacrificio': a saber, consagrados y sirviendo en todo tiempo a nuestra $f e$, perseverando en ella y alejados de toda avaricia, sin adquirir ni poseer terrenos en la tierra. Rebelábase empero en (el sábado) el descanso de Dios para las cosas creadas; esto es, el reino en que, por descansar el hombre, aquel que perseverare en el servicio de Dios, tomará parte en la mesa de Dios"83.

${ }^{81} \mathrm{AH} \mathrm{IV,8,2} \mathrm{(SC} \mathrm{100**,} \mathrm{p.} \mathrm{468):} \mathrm{"Non} \mathrm{enim} \mathrm{prohibebat} \mathrm{lex} \mathrm{curari} \mathrm{homines} \mathrm{sabbatis,} \mathrm{quae}$ et circumdebat eos in hac die, et pro populo ministeria (leitourgían) jubebat sacerdotibus perficere, sed et mutorum animalium curationem non prohibebat".

82 Cf. AH IV,8, 3.

83 AH IV,16,1 (SC $100 * *$, pp. 560-562): "Sabbata autem perseuerantiam totius diei erga Deum deseruitionis edocebant: Aestimati enim sumus ait Apostolus Paulus, tota die ut oues 
"En el libro IV habíase extendido largamente Ireneo en probar que el verdadero sacerdocio de Dios está vinculado al justo, no al linaje carnal. A título de sacerdotes, los justos y discípulos todos del Señor, pueden trabajar en sábado y profanarlo, sin incurrir en culpa... A quienes por haber hecho del Señor en esta vida su heredad, merecieron ser del linaje sacerdotal y levítico de la Nueva Ley, les promete el propio Señor, por boca de Jeremías, la posesión de la Tierra, y saciarlos de todos los bienes terrenos preparados por El. Los justos llamados a la mesa de Abrahán, Isaac y Jacob serán ministrados por el propio Hijo de Dios. El mismo será el servidor del banquete sacerdotal" 84 .

"En el libro anterior declaramos cómo son Levitas y sacerdotes todos los discípulos del Señor; los cuales profanaban el sábado en el Templo, sin incurrir en culpa (c. Mt 12,5). Según eso, tales promesas indican clarísimamente el festín de la creación sensible que, fiel a su palabra, ha de servir Dios en el reino de los justos" 85 .

El mismo que nos ha prestado el servicio en nuestra formación, nos acompaña con su permanente enseñanza. La conexión entre ministerio y magisterio del Verbo le permite al obispo de Lyón subrayar que el ministerio mira singularmente a enseñar, a exponer la doctrina auténtica. Ejercer el ministerio es hacer presente la pedagogía de Dios. Mas es posible ejercer el ministerio sólo después de recibir y conocer lo que los apóstoles pensaron como servidores del Verbo ${ }^{86}$. El Verbo enseña porque ha sido el servidor y desde aquí está garantizada la enseñanza.

Los ministerios que no estén enraizados en Cristo podrán hacer prodigios pero éstos no procederán de la virtud divina sino que serán hechos por obra de magia: "Esto (lo dice) no vaya nadie a creer que hace prodi-

occisionis; scilicet consecrati et ministrantes (leitourgountes) omni tempore fidei nostrae et perseuerantes ei et abstinentes ab omni auaritia, non acquirentes neque possidentes thesauros in terra. Manifestabatur autem et tamquam de eis quae facta sunt requietio Dei, hoc est regnum in quo requiescens homo ille qui perseuerauerit Deo assistere participabit de mensa Dei".

${ }^{84}$ Cf. A. Orbe, Teología de San Ireneo.... o.c., III, pp. 478.

${ }^{85} \mathrm{AH} \mathrm{V,34,3} \mathrm{(SC} \mathrm{153**,} \mathrm{p.} \mathrm{432):} \mathrm{"Ostendimus} \mathrm{autem} \mathrm{in} \mathrm{superiori} \mathrm{libro} \mathrm{quoniam} \mathrm{leuitae} \mathrm{et}$ sacerdotes sunt discipuli omnes Domini, qui et sabbatum in templo profanabant et sine culpa sunt. Tales itaque promissiones manifestissime in regno justorum istius creaturae epulationem significant, quam Deus repromittit ministraturum (diakonesein) se".

${ }^{86} \mathrm{AH} \mathrm{IV}$, praef 3 (SC 100**, p. 386): "In eo igitur qui ante hunc est liber ostensa est de his omnibus sententia Apostolorum, quoniam non solum nihil tale senserunt qui ab initio speculatores et ministri fuerunt Verbi $(\operatorname{Lc} 1,2)$ ueritatis, sed et praedicauerunt nobis fugere huiusmodi sententias, Spiritu prouidentes eos qui seducturi erant simpliciores". 
gios por virtud divina, sino por obra de magia. Y no es de admirar que por ministerio de los demonios y espíritus apóstatas obre prodigios con que seduzca a los habitantes de la tierra" 87.

La diferencia entre el ministerio de los seguidores del Anticristo y de Cristo es tan distante y diverso como lo es Cristo del Anticristo aunque sean asimismo hipourgountes (servidores). La diferencia no radica tanto en los prodigios realizados cuanto en virtud de quién se realizan.

Dios no necesita de los humanos servicios; pues nos crea para tener en quien depositar sus beneficios 88 :

"Así pues, al principio no plasmó Dios a Adán porque necesitara del hombre, sino para tener en quién depositar sus beneficios" 89 .

Por tanto, tampoco Dios necesita del ministerio de los hombres:

"Tampoco mandó (el Salvador) que le siguiéramos porque tuviera necesidad de nuestro servicio, sino para atribuirnos a nosotros (el mérito de) la salvación" 90 .

El único servicio, ministerio o diakonia necesaria es el del Hijo. El ministerio de Jesús sobresale en la escena de la última Cena:

"Pues quien lavó los pies de los discípulos santificó el cuerpo entero y lo llevó a limpieza. Por eso a los que estaban recostados (en la Cena) servíales de comer. Daba a entender a los (difuntos) que estaban recostados en la tierra; a los cuales vino a servirles la Vida"91.

La Cena del Señor con los suyos a los que sirve la comida es figura de la Vida que el mismo Señor les donará evangelizándoles y resucitándoles. Quien realiza el verdadero servicio es Jesús. Ireneo une a la escena de la Cena la salvación de todos, salvación a la que está dirigido todo servicio que nazca del servicio de Jesús en la cena con los suyos. El acto figurati-

${ }^{87} \mathrm{AH} \mathrm{V}, 20,2$ (SC $153^{* *}$, p. 354): "Hoc ne quis cum divina uirtute putet signa facere, sed magica operatione. Sed non est mirandum si, daemoniis et apostaticis spiritibus ministrantibus (hipourgountos) ei, per eos faciat signa in quibus seducat habitantes super terram". Cf A. Orbe, Teología de San Ireneo..., o.c., III, p. 181.

88 Cf A. Orbe, Espiritualidad de San Ireneo. Analecta Gregoriana 256, Rorna 1989, pr,. $45-$ 89.

${ }^{89}$ AH IV,14,1 (SC 100**, p. 538): "Igitur initio, non quasi indigens Deus hominis, plasmauit Adam, sed ut haberet in quem collocaret sua beneficia".

90 AH IV,14,1 (SC 100**, p. 538): "Neque nostro ministerio (diakonias) indigens jussit ut eum sequeremur, sed nobis ipsis attribuens salutem".

91 AH IV,22, 1 (SC 100**, p. 686): "Quapropter et recumbentibus eis ministrabat (ediako$n e i)$ escam, significans eos qui in terra recumbebant, quibus uenit ministrare (diakonesai) uitam, sicut Hieremias ait. 
vo de Jesús, el lavar los pies, es el más bello ejemplo de diakonia, en el que se resumen los actos prefigurativos (dispensaciones) que han tenido lugar en la historia y debe ser continuado por la Iglesia ${ }^{92}$.

El servicio de Cristo conlleva la recompensa o el cumplimiento de todos los vaticinios proféticos. Es iluminador el parangón Lc 12,37 (“dichosos los criados a quienes el amo al llegar, los encuentre velando: os aseguro que se ceñirá, los hará recostarse a la mesa y les irá sirviendo") e Is 58,14 ("entonces te gozarás en Yahweh, y te haré remontar sobre las alturas de la tierra, y te dará a conocer la herencia de Jacob, tu padre, pues la boca de Yahweh ha hablado"). El Señor toca servir personalmente a los justos, a los que sentará en la mesa de los patriarcas ${ }^{93}$. La parábola de los siervos vigilantes (Lc $12,37)$ contiene ricos matices que complementan el pensamiento ireneano. En lo que al ministerio de Jesús se refiere hay que tener en cuenta que el servicio de Cristo culmina con la recompensa de los justos. Y dentro de la relación de éstos últimos alude el obispo de Lyón a los diferentes estados en la comunidad eclesial ${ }^{94}$. Y la recompensa de los justos es para el Señor, como sacerdote oferente, ofrendar al Padre el hombre convertido, la oveja perdida y hallada. Jesús es el ternero cebado muerto para hacer posible que ninguno se pierda. A este propósito sería iluminador perseguir las exégesis de las parábolas y descubrir el pensamiento ireneano sobre el ministerio o sacerdocio de Cristo, en particular la interpretación de la parábola del hijo pródigo en relación con el sacerdocio de Cristo 95 .

"Dios preparó a los justos ex gentibus para ministerio de los santos"96. Esta expresión indica, una vez más, que Ireneo al insistir sobre el servicio (diakonia) no piensa únicamente en los que están constituidos en el ministerio de la administración de la Palabra. El obispo de Lyón piensa más bien que los justos todos están llamados a la diakonía y que ésta es una realidad común para todos los seguidores de Jesús. A este propósito es indicativo el pasaje de Ireneo:

92 Cf AH IV,22,1; cf. A Orbe, Teología de San Ireneo..., o.c., IV, ad loc.

93 AH V,34,2 (SC 153**, p. 426-428): "Hoc est quod et a Domino dictum est: Beati serui illi, quos ueniens Dominus inueniet uigilantes: amen dico uobis quoniam praecingetur et recumbere eos faciet et transiet ministrabit (diakonesei). Et si uenerit uespertina uirilia et inuenerit sic beati sunt quoniam recumbere eos faciet et ministrabit (diakonesei) eis: licet secunda. et licet tertia, beati sunt".

94 Cf. A. Orbe, Teología de San Ireneo.... o.c., IH, pp. 462-464.

95 Cf. AH III,11, 8.

96 Cf. AH V,35, I. 
"En cambio, a cuantos de entre las naciones dispuso Dios a fin de multiplicar en la tierra a los remanentes y someterse al reino de los santos y servir a Jerusalén, y ser reino en ella, los significó así el profeta Jeremías..."97.

Ireneo recuerda dos pasajes bíblicos: 1 Cor 16,15 ("los gentiles de la casa de Estéfano se consagraron al servicio de los santos"), y Act 6,2 ("No parece bien que nosotros, dejada de lado la palabra de Dios, nos empleemos en servir a las mesas"). A. Orbe explicita el sentido del paso ireniano: "Los justos de la gentilidad fueron preparados por Dios para diaconía de Jerusalén. Rebeca, venida de gentiles, para servir a Isaac, el hijo de Abrahán. Servir a Jerusalén, en clave matrimonial, es auxiliar como Esposa- a Israel (marido). Y a nivel escatológico, lo que en los días del Apóstol servir a los santos (de Jerusalén: 1 Cor 16,1.15; 2 Cor 8,4; 9,1.12). En los Hechos fueron ordenados los diáconos para 'servir a las mesas'; en los tiempos del reino, los justos venidos de la gentilidad servirán a las tres mesas de los santos, presididas por Abrahán, Isaac y Jacob. Diáconos de esta Jerusalén, presidida por los tres Patriarcas, lo son también del Reino (resp. de los santos)" ${ }^{\prime \prime 9}$.

En exégesis a 2 Cor 3,3 ("Pues sois epístola de Cristo, redactada por ministerio de nosotros, escrita... en las carnales carnes del corazón") el obispo de Lyón insiste en la dimensión pneumatológica del ministerio del Verbo, y por ende, en todo ejercicio ministerial:

"Y en la misma carta dice cómo abraza el Espíritu a la carne (2 Cor 3,3): Pues sois epístola de Cristo redactada por ministerio de nosotros escrita no con tinta, sino con Espíritu de Dios vivo, no en tablas de piedra. sino en las carnales tablas del corazón. Ya que ahora, pues, los corazones de carne se vuelven capaces de Espíritu, ¿cómo extrañar que en la resurrección contengan la vida otorgada por el Espíritu?"99.

97 AH V,35,1 (SC 153**, p 440): “et quotquot ex gentibus ad hoc praeparauerit Deus ad derelictos multiplicandos in terra et sub regno sanctorum fieri et ministrare (diakonein) in Hierusalem..."; cf A. Orbe, Teología de San Ireneo..., o. c., III, pp. 478-480.

98 Cf. A. Orbe, Teología de San Ireneo..., o.c., III pp. 509.

99 AH V,13,4 (SC 153**, p. 176): "Et quoniam Spiritus complectitur carnem, in eadem epistola ait: Quoniam estis epístola Christi, ministrata (diakonetheisa) a nobis. inscripta non atramento sed Spiritu Dei uiui. non in tabulis lapideis sed in tabulis cordis carnalibus (2 Cor 3,3). Si ergo nunc corda carnalia capacia Spiritus fiunt, quid mirun si in resurrectione eam quae a Spiritu datur capiunt uitam?...”. 
Ireneo piensa que la carta escrita por ministerio apostólico son los corintios en carne. El cuerpo y carne de los bautizados en Espíritu con el que se imprimieron las Escrituras. El ministerio del Apóstol alcanza un realismo especial al insistir en la función del Espíritu en la carne, en este caso en la carne de todos los fieles ${ }^{100}$. La teología del ministerio logra nuevos acentos con la insistencia de la función pneumatológica en la sarx.

$\mathrm{Si}$ es de considerar de una singular importancia la pneumatología en la cristología (resp. en la antropología), no lo es menos el papel del Espíritu en la teología del ministerio. El principio fundamental de la encarnación del Verbo es que la carne es capaz del abrazo del Espíritu y el apóstol -el ministerio en la Iglesia- señala el cómo de este abrazo. Sería de gran interés explicitar la rica relación entre ministerio y penumatología establecida por Ireneo.

\section{El episcopado y el presbiterado y el beneplácito del Padre}

Pero las alusiones al ministerio ordenado, en la obra ireneana, aparecen también en las muchas referencias a la figura del obispo, del presbítero y del diácono ${ }^{101}$. J. A. de Aldama estudió la terminología ireneana referente al ministerio ordenado y el uso de sacerdos, sacerdotalis, sacerdotium, episcopatus, episcopus, presbyter, presbyterium, senior, minister, ministerialis, ministerium, ministratio, ministrare. etc ${ }^{102}$. Al episcopado le califica su conexión específica a la sucesión de los apóstoles. Suceder (diadoché) conlleva referirse a los apóstoles para ser lo que ellos han sido y, por lo tanto, mantener el apostolado. Los gnósticos hablaban también de sucesión (diadoché), usaban el mismo término, pero entendían una realidad distinta ${ }^{103}$.

100 Cf A. Orbe, Teología de San Ireneo..., o.c., 1, pp. 642-643.

101 Así como las referencias a la figura del obispo y del presbítero son abundantes e íntimamente interrelacionadas, no del mismo modo el perfil que Ireneo nos presenta del diácono y diaconado. Véase AH I,13,5; 1,14,7; III,12,10.

102 Cf. J. A. Aldama, El sacerdocio ministerial en san Ireneo..., a.c.

103 AH II,20,2 (SC 294**, p. 202): "Iudas autem abdicatus est et eiectus, et in locum eius Matthias ordinatus est, secundum quod scriptum est: Et episcopatus eius accipiat alius (Act 1,20)". Cf A. Orbe, Ideas sobre la Tradición en la lucha antignóstica, Augustinianum 12/1 (1972)19-35; M. M. Garijo, La sucesión apostólica en los tres primeros siglos, Diálogo Ecuménico 2 (1976) 179-231; AA.VV., Le Tradizione: forme e modi. XVIII Incontro di studiosi dell'antichita cristiana, Roma 1990. 
Los apóstoles, después de fundar las iglesias, confiaron a sus sucesores el servicio del episcopado por ser sus receptores y para ser sus continuadores ${ }^{104}$. Lino recibió el episcopado de Clemente, Eleuterio fue elegido en duodécimo lugar después de los apóstoles para ejercer esta función ${ }^{105}$ e Higinio tenía el octavo puesto de la sucesión episcopal a partir de los apóstoles en la iglesia de Roma ${ }^{106}$. Se contrasta a Cerdón y a Marción con alguien que en la sede romana ha sucedido a los apóstoles. Frente a los sectarios se sitúa la Magna Iglesia ${ }^{107}$. No es necesario repetir que las listas episcopales más que un argumento histórico quiere ser un argumento teológico.

Es sabido que Ireneo intercambia la terminología presbítero-obispo ${ }^{108}$. Los presbíteros suceden a los apóstoles y reciben en la sucesión en el episcopado, por beneplácito del Padre, el carisma seguro de la verdad:

"Por eso conviene obedecer a los presbíteros de la Iglesia, que suceden a los Apóstoles según indicamos; los cuales con la sucesión en el episcopado recibieron, por beneplácito del Padre, el carisma seguro de la verdad"109.

El ministerio nace del beneplácito del Padre y éste es el que asegura y sella la verdad que acompaña al ministerio ${ }^{110}$. La dispensación de la salvación, para la cual existe todo ministerio, tiene su inicio en el benepláci-

104 AH III,3,3 (SC 211**, p. 32-34): "Fundantes igitur et instruentes beati apostoli Ecclesiam, Lino episcopatum administrandae (Episcopes leitourgian) Ecclesiae tradiderunt:...Post eum tertio loco ab apostolis episcopatum (episcopen) sortitur Clemens, qui et uidit apostolos ipsos, et contulit eum eis et cum adhuc insonantem praedicationem apostolorum et traditionem ante oculos haberet, non solus: adhuc enim multi supererant tunc ab apostolis docti".

105 AH III,3,3 (SC 211**, p. 36): “Cum autem successisset Aniceto Soter, nunc duodecimo loco episcopatum (episcopes) ab apostolis habet Eleutherus".

106 AH I,27,1 (SC 264**, p. 348): "Et Cerdon... cum uenisset Romam sub Hyginio, qui nonum locum episcopatus (episcopes) per succesionem ab apostolis habuit".

107 Cf. AH I,27,1; III, 4,3.

108 Cf. AH II,22,5; III,2,2; III,3,2 IV,26,2; V,20,1. Las alusiones al Presbítero (¿obispo?): cf. AH IV,27,1; IV,28,1; IV,30,1; IV,31,1; IV,32,1; IV,33,3; V,36,1.2; cf A. Orbe, Teología de San Ireneo..., o.c., I, p. 245.

${ }^{109}$ AH IV,26,2 (SC 100**, p. 718): “Quapropter eis qui in Ecclesia sunt Presbyteris (Presbiterois) obaudire oportet, his qui successionem (diadochen) habent ab Apostolis, sicut ostendimus, qui cum episcopatus (episcopiké) successione charisma ueritatis certum secundum placitum Patris acceperunt..."; cf A. Orbe, Teología de San Ireneo..., o.c., IV, ad loc.

110 Los términos beneplacitum y placitum son muy usados en Ireneo y son capitales para su teología. Cf AH I,9,3; I, 10,1; I, 12,4; 1,13,2; II,5,3; II,32,5; III,11,9; III,19,6; III,20,2; III, 23,1; IV,5,4; IV,6,3; IV,9,3; IV,20,3; IV,20,8; IV,20,12; IV,26,2; IV,27,1; V,1,3. 
to del Padre, desde los comienzos de la historia humana, desde los días de Adán hasta los "tiempos novísimos", es decir, desde los días del Evangelio hasta los tiempos de la plenitud. El ministerio permanecerá el tiempo que dure la historia de la dispensación salvífica.

Ireneo cuando alude al beneplácito del Padre se basa en Hech 1,7 ("no os toca a vosotros conocer los tiempos o momentos oportunos que el Padre fijó con su propia potestad"), en Mt 10,20 ("que no seréis vosotros los que hablaréis, sino el Espíritu de vuestro Padre quien hablará en vosotros...") y en Mt 28,18-20111. El obispo de Lyón silencia Mt 28,18 ("data est mihi onmis potestas in caelo et in terra") pero cita Mt 28,19. El poder que Jesús recibió del Padre y que comunicó a sus apóstoles para perpetuarse en la sucesión episcopal no es solo un poder bautismal sino también doctrinal: asegurar el carisma de la verdad mediante el Espíritu del Padre que habló en los apóstoles y hablará en sus sucesores. Este es el aspecto más acentuado por S. Ireneo.

Probablemente la expresión "placitum Patris" se inspire en Ef 1,9: ("notificándonos el misterio de su voluntad, según su beneplácito, que se propuso en él") 112 . El "carisma cierto de la verdad", seguro, firme, incorruptible, incontaminado ${ }^{113}$-que no fue inventado por los apóstoles o por sus sucesores- encierra posiblemente una alusión a Jn 15,26; 16,13 ("cum autem uenerit ille Spiritus ueritatis, docebit uos omnem ueritatem"). Se apunta aquí y se corrobora la íntima relación entre el Espíritu y el ministerio.

Los Apóstoles tuvieron el "carisma cierto de la verdad" por voluntad del Padre y por institución de Cristo. La misión institucional del Hijo del ministerio de la diadoché no esconde otra cosa que el querer del Padre y el "carisma de la verdad" es un don que garantiza permanecer en la voluntad de Dios. Los sucesores de los apóstoles lo han sido por voluntad explicita de los mismos apóstoles. Y tan seguro era el "carisma de verdad" en los apóstoles como en sus sucesores. Así como los patriarcas y profetas fueron adornados con el carisma de profecía, de modo similar los sucesores de los apóstoles lo fueron con el "carisma de verdad", al igual que los primeros seguidores del Señor.

\footnotetext{
111 Cf. AH III,17,1.

112 Cf. AH I,9,3;I,10,1; III,11,9;III,16,1;III,20,2; III,23,1.

113 Cf. AH IV,26, 5.
} 
La sucesión mira, pues, a la verdad. Ireneo subraya que los que no aceptan la sucesión apostólica se apartan del acontecimiento fundante, de la verdad manifestada por el Señor, y así estarán siempre embarcados en una perpetua inquisición, buscando en todos los lugares ${ }^{114}$. No acoger el ministerio apostólico significa optar por la dispersión frente a la sencillez de la verdad. Ireneo piensa en aquellos que no se atienen a lo transmitido por los sucesores de los doce y evoca a Mt 12,30 (Lc 11,23) ("qui non colligít mecum dispergit") ${ }^{115}(\mathrm{III}, 3,2)$. El verbo colligere recuerda a Ireneo la metáfora de la siega refiriéndose a la simiente (Cristo) diseminada a lo largo y ancho del AT y recogida en el NT por los apóstoles y sucesores. El ejercicio del ministerio de la sucesión exige estar atentos a recoger las semillas diseminadas, afincarse en la Palabra del A. y N.T. Al sucesor de los apóstoles se le requiere estar con la semilla (Cristo), en la Palabra; le caracteriza el asentamiento en la continuidad de la profecía en el cumplimiento.

Ireneo alude y tipifica a tres grupos que se separan de la auténtica sucesión: los herejes que son los que buscan fuera de lo propio, al estilo de Nadab y Abiud; los que, en el interior de la Iglesia, son engreídos, insumisos y que caminan al margen de los verdaderos sucesores; éstos encuentran sus precedentes en Coré, Datan y Abirón; y, finalmente, los cismáticos, los que han osado separarse de la Magna Iglesia.

Los cismáticos tienen su referencia en Jeroboán (la división del reino de Israel del de Judá) ${ }^{116}$. Entre los segundos hay que incluir a los falsos presbíteros o sucesores de los apóstoles, los que viven de modo distinto a lo que profesan. Son un mal intestino. Los que no tienen conducta sana para poder confiar en la verdad y poder reprender, aquellos que ante el pueblo sencillo pasan por buenos porque ignoran sus obras, los maleados por el lucro, la vanidad y la malicia. Ireneo en el libro IV traza los perfiles - procedentes de la exégesis anteriores a él- de lo que debe ser y no ser los transmisores de la verdad apostólica:

"Mas a los que a juicio de muchos pasan por presbíteros, son esclavos de placeres, y, lejos de gobernarse en su interior por el temor de Dios, ultrajan a los demás y se enorgullecen hinchados por el puesto de mando,

114 Cf. A. Orbe, Parábolas evangélicas de San Ireneo, Madrid 1972, I, pp. 62-74.

115 Cf. AH III,3,2.

116 Cf. IV,36,2. Ireneo no alude a ejemplos ni a actitudes que reflejen la posición de los herejes, de los insumisos y de los cismáticos en el N.T. 
y obran mal a escondidas, y dicen (Dan 13,20): 'Nadie nos ve'. Serán confundidos por el Verbo, que no juzga según opinión (cf. Is 11,3), ni mira al rostro, sino al corazón (cf. Sam 16,7). Y oirán las palabras del profeta Daniel (13,56.52-53): 'Raza de Canaán y no de Judá, la hermosura te sedujo y la concupiscencia pervirtió tu corazón. Inveterado de los días malos, ahora vinieron (a descubrirse) los pecados que antes hacías, juzgando los juicios injustos. Condenabas a los inocentes, y absolvías a los culpables. Decía (empero) el Señor: No darás muerte al inocente y al justo'. De ellos dijo también el Señor (Mt 24,48-51:Lc 12,45-46) ${ }^{117}$ :

"Conviene por tanto apartarse en absoluto de tales individuos y allegarse a quienes, según dijimos arriba, custodian la sucesión de los Apóstoles, y juntan con el orden presbiteral una palabra sana y una conducta irreprochable (cf. Tit 2,8 ) para ejemplo y enmienda de los demás. De esta suerte Moisés...Igualmente Samuel... Igualmente el apóstol Pablo"118.

La verdad que se encuentra en la Tradición recibida de los apóstoles, junto a la fe anunciada a los hombres, llega hasta nosotros por medio de la sucesión de los apóstoles ${ }^{119}$. Tradición va unida a la fe y a la sucesión y pueden encontrarla cuántos quieran pues está en íntima conexión con los obispos establecidos por los mismos apóstoles ${ }^{120}$. No es difícil saber quién es el sucesor de los apóstoles en la Iglesia teniendo en cuenta que los buenos presbíteros son figurados en el AT por Moisés y Samuel y en el N.T. por Pablo. Según Isaías son jefes animados de paz y justicia. El Señor los define doctores, como intendentes fieles, buenos y sabios. El Apóstol los menciona como apóstoles, profetas y doctores ${ }^{121}$.

El mismo Pablo convocó en Mileto a los obispos y presbíteros de Éfeso y despidiéndose de ellos les deja su testamento, a saber Act. 20,25-

117 AH IV,26,3 (SC 100**, pp. 720ss.)”. Pablo”; cf. IV,26,5; A. Orbe, Teología de San Ireneo..., o.c., IV, ad loc.

118 Cf. AH IV,26, 4

119 AH III,3,2 (SC 211**, p. 32): “...eam quam habet ab apostolis traditionem et adnuntiatam hominibus fidem per successiones episcoporum (diadochás tón episcópon) peruenientem usque ad nos indicantes...".

120 AH III,3,1 (SC 211**, p. 30): "Traditionem itaque apostolorurn in toto mundo manifestatam in omni Ecclesia adest perspicere omnibus qui uera uelint uidere, et habemus adnumerare eos qui ab apostolis instituti sunt episcopi (episcopous) in Ecclesiis et successores eorum usque ad nos...".

${ }^{121} \mathrm{AH}$ IV,26,5 (SC 100**, pp. 726-728): “Tales presbyteros nutrit Ecclesia. De quibus propheta ait: (Is 60,17$) \ldots$ De quibus et Dominus dicebat...". 
28 ("mirad por vosotros mismos y por toda la grey, en medio de la cual el Espíritu Santo os puso por obispos para pastorear la Iglesia de Dios, que él hizo suya con su propia sangre") ${ }^{122}$. La Tradición apostólica se conserva en la Iglesia gracias a la sucesión de los presbíteros. Poseer la doctrina de los apóstoles equivale a tener acceso a la Palabra. Por ello mismo la adhesión a los presbíteros/ obispos es igual a la aceptación de las Escrituras $^{123}$. Los herejes -en especial los gnósticos- se oponen a los presbíteros alegando que son más sabios que los presbíteros y los apóstoles, y que éstos han mezclado las palabras del Salvador con las prescripciones de la ley ${ }^{124}$, acusándoles de imperitos ${ }^{125}$. Ireneo defiende de esta acusación a los presbíteros respondiendo que más vale la santidad que la ignorancia. Pero, por otra parte, no hay que olvidar que los gnósticos no dirigían sus diatribas contra la santidad sino contra la impericia.

Si el ministerio apostólico es debido al beneplácito del Padre y goza del "carisma seguro de la verdad", es debido al Espíritu que otorga la gnosis de la verdad. Y entre los contenidos de la gnosis sobresale el distintivo del Cuerpo de Cristo conforme a la sucesión de los obispos ${ }^{126}$.

El maestro de Ireneo, Policarpo, es presentado como un ejemplo a seguir en el ministerio ${ }^{127}$. Policarpo, amaestrado por los apóstoles, fue establecido como obispo ${ }^{128}$. Y, junto al maestro mártir, están los sucesores que conoció Ireneo. Valdría la pena arrancar de los escritos de Ireneo el

122 AH III,14,2 (SC $211^{* *}$, p. 264): “Quoniam autem Paulus simpliciter... In Mileto enirn conuocatis episcopis et presbyteris qui erant ab Epheso”. Aquí se distingue presbyter de episcopus.

123 AH IV,32, 1: "Y en segundo lugar, toda palabra tendrá consistencia para él, siempre que lea también con esmero las Escrituras, entre los presbíteros de la Iglesia, entre los cuales se halla, según hemos demostrado, la doctrina de los Apóstoles".

124 AH III,2,2 (SC $211^{* *}$, pp. 26-27): “Cum autem iterum ad eam traditionem quae est ab apostolis, quae per successiones presbyterorurn in Ecclesiis custoditur, prouocamus eos, aduersantur traditioni, dicentes se non solun presbyteris".

125 Cf. V,20,2.

126 AH IV,33,8 (SC 100**, p. 818-820): “Agnitio uera est Apostolorum doctrina, et antiquus Ecclesiae status in uniuerso mundo, et character corporis Christi secundum successiones episcoporum (diadochás tón eriskóron) quibus illi eam quae in unoquoque loco est Ecclesiam tradiderunt...".

127 Cf. A. Orbe, En torno a una noticia sobre Policarpo. (Ireneo Adversus Haereses III,3,4) en: Studí sul cristianesimo antico e moderno in onore di Maria Grazia Mara, Roma 1995, II, pp. 597-604 (=Augustinianum 35 (1995) 597-604).

${ }^{128}$ AH III,3,4 (SC $211 * *$, p. 38): "Et Policarpus...sed etiarn ab apostolis in Asia in ea quae est Smyrnis Ecclesia constitutus episcopus (episcopos)...” 
modelo de obispo/presbítero según los ejemplos que él conoció y las noticias y exégesis que a él llegaron.

Concluyendo: los textos de S. Ireneo que aluden al ministerio han sido repetidamente estudiados y reconocidos en su justo valor en la historia del pensamiento teológico. Es harto conocido que el obispo de Lyón no se preocupa de subrayar la dimensión sacrificial del ministerio. Se interesa de un modo especial por el servicio que prestan a la Iglesia los sucesores de los apóstoles - presbíteros/obispos ${ }^{129}$ - adornados con el "carisma cierto de la verdad" y que son transmisores garantizados de la auténtica Tradición apostólica. Sin embargo, el obispo Ireneo no olvida la dimensión ministerial de todos los bautizados sean o no constituidos en la sucesión de los apóstoles. Una y otra vez alude a los seguidores de Jesús y al ministerio como consecuencia del seguimiento.

Con todo no es ocioso volver sobre textos mil veces leídos. Estos conservan perfiles y aspectos inagotables. Así el análisis del adverbio simpliciter (con sencillez) abre perspectivas nuevas y, por su frecuencia e insistencia, descubre la imagen del que ejerce el ministerio en la Iglesia. Y, junto al término arplós, las expresiones contrarias que -a contrarioamplían lo que el obispo de Lyón quiere enseñar. No menos importancia adquiere el contemplar el ministerio desde la teología trinitaria -el Verbo y el Espíritu como diáconos de las dispensaciones salvíficas del Padre- y sus consecuencias en la antropología.

La teología pre-nicena, y la de Ireneo de modo particular, se presenta asombrosamente unitaria. Puede que sea esta nota la que más resalta su madurez. A la luz de esta característica brilla con especial fuerza la íntima conexión del misterio con el beneplácito del Padre, el ministerio del Hijo, la eficacia del Espíritu en la creación y en la consumación de lo creado. La cristología y la pneumatología aparecen como los únicos ojos con los que se puede contemplar todo servicio cristiano. La visibilidad (encarna-

129 En S. Ireneo presbyter equivale a epíscopus. Cf., a este propósito, Eusebio de Cesarea, Historia Eclesiástica V,24, 14 (Carta de S. Ireneo al Papa Víctor) (ed. A. Velasco 1, p. 335): "Entre ellos, también los presbíteros (presbíteroi) antecesores de Sotero, que presidieron la iglesia que tú riges ahora, quiero decir Aniceto, Pío e Higinio, así como Telesforo y Sixto..."; V,24,15: "Y nunca se rechazó a nadie por causa de esta forma, antes bien, los mismos presbíteros (presbíteroi), tus antecesores, que no observaban el día...". Cf. AH IV,26,2-5; IV,32, 1; III,3,3. Es difícil negar que el presbítero del AH IV sea un obispo de las iglesias de Asia (AH IV, 27,$1 ; 28,1 ; 30,1 ; 31,1 ; 32,1)$. 
ción) del Hijo sella la importancia del ministerio en la salvación de la humanidad. El obispo de Lyón sabía muy bien que el ministerio eclesial, la mediación, y ésta cristianamente (según la Magna Iglesia) entendida, estaba muy lejos de la Eclesiología gnóstica. La opción por la visibilidad o por la invisibilidad arrastraba a la afirmación o la negación del ministerio. Soy consciente de que he señalado algunos aspectos a modo de apuntes. Estoy seguro que el análisis y estudio sistemático de todos los pasajes bíblicos, explícitos e implícitos, que pueden referirse a la temática del ministerio enriquecería la teología ministerial que San Ireneo nos quiso transmitir.

+ Eugenio Romero Pose In memoriam 